Portland State University

PDXScholar

1973

\title{
Solid Casting in Aluminum and Concrete Using the Multiple-piece plaster mold: a method of introducing the Adolescent Student to the Indirect Method of Sculpture
}

Donald LeRoy Sandblast

Portland State University

Follow this and additional works at: https://pdxscholar.library.pdx.edu/open_access_etds

Part of the Art Education Commons, Art Practice Commons, and the Secondary Education and Teaching Commons

Let us know how access to this document benefits you.

\section{Recommended Citation}

Sandblast, Donald LeRoy, "Solid Casting in Aluminum and Concrete Using the Multiple-piece plaster mold: a method of introducing the Adolescent Student to the Indirect Method of Sculpture" (1973).

Dissertations and Theses. Paper 1613.

https://doi.org/10.15760/etd.1612

This Thesis is brought to you for free and open access. It has been accepted for inclusion in Dissertations and Theses by an authorized administrator of PDXScholar. Please contact us if we can make this document more accessible: pdxscholar@pdx.edu. 
AN ABSTRACT OF THE THESIS OF Donaid LeRoy Sandblast for the Master of Scierice in Teaching presented April 30, 1973.

Title: Solid Casting in Aluminum and Concrete Using the Multiple-Fiece Plaster Hoid: A Method of Introducing the Adolescent Student to the Indirect Method of Sculpture.

APPROVED BY MEMBERS OF THE THESI\& COMMITTEE:

Jămes L. Hănsen, \&hairm,

Robert S. Morton

Or. Leonard B. Kimbre?]

This thesis deals with an investigation of the feasibility of using the multiple-piece plaster mold as a vehicle for teaching the indirect method of scuiptire to the adolescent student.

It is based upon the assumption that the students invoived in the processes described will have had previous experience with the tools, techniques, and materials to be used.

The investigation centered around the ability of the students to express thenselves through the development of a sculptural furm. The teacher's role was to assist the student in identifying, expressing, and 
evaluating his individual goals against those goals established by the teacher. Instructional goals were present, but relegated to being of secondary importance to those goals possessed by the student.

My research established the physical possibilities of casting both in aluminum and concrete using the multiple-piece plaster mold. Research procedures centered around the investigations of industrial methods used in forming aluminum castings in plaster molds. My investigation revealed that solid aluminum castings in plaster molds offered exciting artistic possibilities, but that rigid control of the preparation of the molds and the casting process was necessary before aluminum casting could be introduced to the students. Concrete casting was also found to be of use in the secondary class room.

Prior to the introduction of casting to the students, a questionnaire was given them to determine their sculptural concepts and their past experience with materials, tools, and techniques. The information gained gave support to the exploration of the casting process.

I then formulated a unit of study designed around the student's successfully completing a solid casting in either aluminum or concrete using the multiple-piece plaster mold. This unit was presented as nine separate problems to be solved in the following sequence: designing in clay, constructing an armature, modeling a temporary clay form, forming a multiple-piece plaster mold, drying the mold, casting, chasing, applying a patina, and mounting a completed casting.

The project was challenging and broadening for the majority of the students involved. They were able to use past experiences with implements, materials, and processes and incorporate these into this new learning situation. Group solutions were found to be the most useful method in 
solving problems in each step. Evidence suggests that group learning through association and cooperative problem solving is the most valuable result of this project.

Aluminum proved to be the most popular material, but from an instructional standpoint it was found to be a much more demanding and complex material. I found that it was important for the students to have had previous experience in the use of similar materials, tools, and methods to those encountered in this project. Due to the complexity of this project, prior knowledge in sculptural concepts is also clearly indicated as being necessary. I conclude with the recommendation that this unit of study be undertaken by advanced students as a summary project after several years of study. 


\title{
SOLID CASTING IN ALUMINUM AND CONCRETE \\ USING THE MULTIPLE-PIECE PLASTER MOLD: \\ A METHOD OF INTRODUCING THE ADOLESCENT STUDENT \\ TO THE INDIRECT METHOD OF SCULPTURE
}

\author{
by \\ DONALD LE ROY SANDBLAST
}

\author{
A thesis submitted in partial fulfillment of the \\ requirements for the degree of

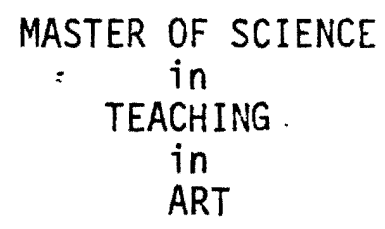

Portland State University

1973 
TO THE OFFICE OF GRADUATE STUDIES:

The members of the Combittee approve the thesis of Donaid LeRoy Sandblast presented Apri] 30, 1973.

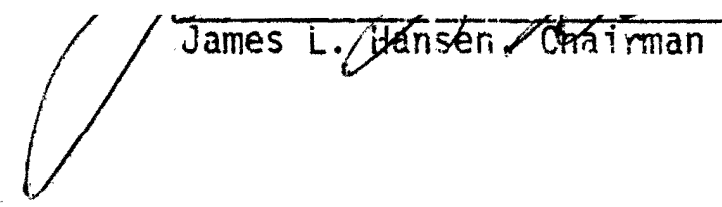

Robert S. Marton

Dr. Kimbrell

APPROVED:

Frederick H. Heidel, Head, Department of Art

Dåvid T. Clark, Dean of Graduate Studies

Apri1 30, 1973 


\section{ACKNOWLEDGMENTS}

I wish to acknowledge my gratitude for the assistance and support of the following individuals during the undertaking of this thesis:

My wife Beverly, miy son Kenny, and my daughter Kellie for their patience, perseverance and understanding; Mr. Herbert Beavers, counselor and former art teacher for his assistance in tests and measurements; Mr. Jack Pfeifer, crafts instructor and head of the industrial arts department, Medford Mid-High School, friend and associate; Mr. Jerry Humphry, metal arts instructor, for his technical assistance and use of the foundry. 
TABLE OF CONTENTS

PAGE

ACKNOWLEDGMENTS ........................

LIST OF TABLES ............................ vi.

LIST OF FIGURES .............................. vii

CHAPTER

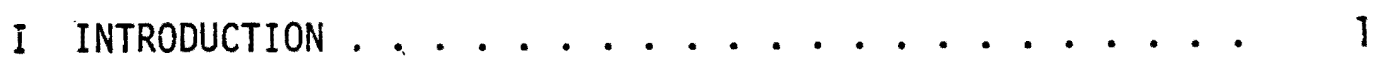

II A PROPOSAL FOR THE SOLUTION TO THE PROBLEM .......4 4

III RESEARCH RELEVANT TO THE SOLUTION OF THE PROBLEM . . . . 6

Uses of Plaster Molds in Industry ........ 6

Research and Experimentation in Casting in

Aluminum and Concrete Via the Plaster Mold ..... 11

Aluminum ................. 1 ?

Concrete .................... 14

Student Questionnaire ........... 16

iV Methods and teCHniques .................. 20

Unit Introduction ................ 20

Phases of Casting as Proposed Problems ........ 21

Problem 1: Creating a Clay Form ......... 21

Problem 2: Construction of an Armature ...... 21

Problem 3: Modeling of a Clay Form Over an Armature. 22

Problem 4: Forming the Plaster Piece Mold ..... 23

Problem 5: Preparing the Mold for Casting ..... 24

Problem 6: Casting ........... 24

Problem 7: Chasing ........... 26

Problem 8: Applying a Patina......... 27

Problem 9: Mounting a Completed Casting ..... 29

$\checkmark$ CONCLUSIONS AND RECOMMENDATIONS ........... 31 
SCULPTURES BY THE STUDENTS ........................ 33

SCULPTURES BY THE AUTHOR ............................. 41

A LIST OF SOURCES CITED . . . . . . . . . . . . . . . . 45

APPENDIX . . . . . . . . . . . . . . . . . . . . 46 
LIST OF TABLES

TABLE

PAGE

I Dry Strength of Plaster as Determined by Consistency of Plaster Water Mix ........ 9

II Standard Permeability ............ 10 
LIST OF FIGURES

PAGE

Sculptures by the Students ................ 33

Figure 1 ............................ 34

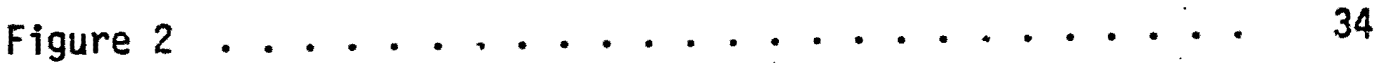

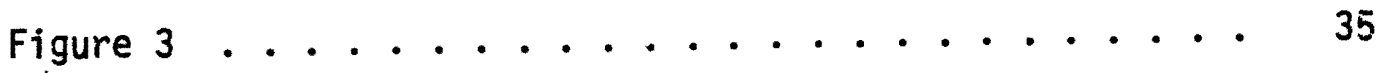

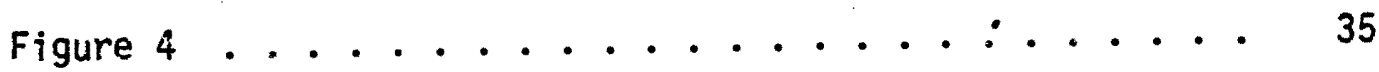

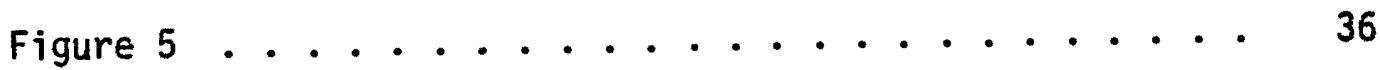

Figure 6 ............................ 36

Figure 7 ........................ 37

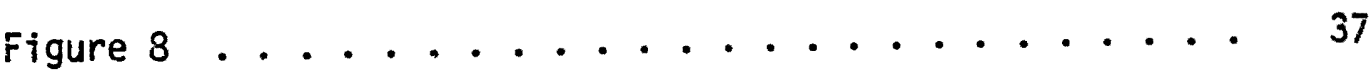

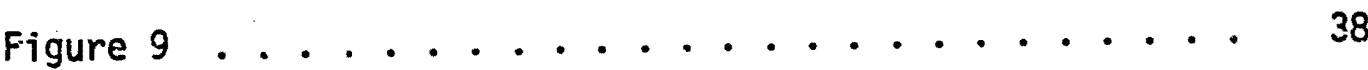

Figure 10 ........................ 38

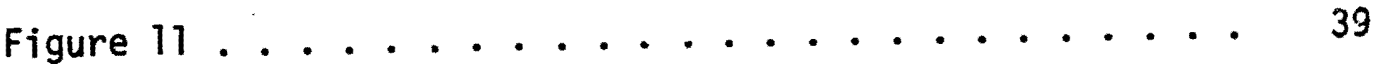

Figure 12 ............................ 39

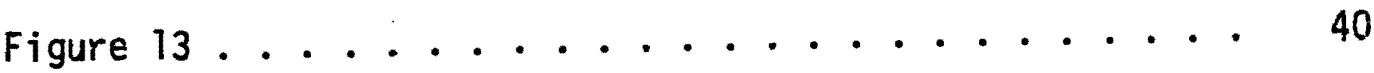

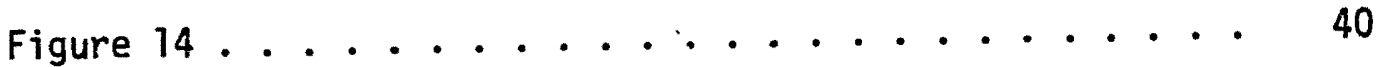

Sculptures by the Author ................. 41

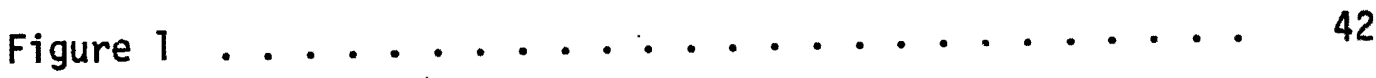

Figure $2 . . . . . . . . . . . .442$

Figure $3 . . . . . . . . . . . . . .442$

Figure 4 ....................... 43

Figure $5 . . . . . . . . . . . . . .443$

Figure 6 ...................... 43 
Figure $7 \ldots \ldots \ldots . \ldots . \ldots . \ldots 4$

figure $8 \ldots \ldots \ldots 44$

Figure $9 . \ldots \ldots \ldots 44$ 


\section{CHAPTER I}

\section{INTRODUCTION}

Even before the earliest of recorded history man has had a natural tendency to engage in sculpture. He has developed knowledge of the use of materials, tools, and techniques out of experiencing his existence. By the process of scratching or through modeling with his hands and fingers, he has developed techniques which have allowed him to make real his need to record those ideas, activities, and thoughts identified as being significant within his existence. The scuiptor is concerned with the concept of the existence of form. It is his ability to make it a reality which separates him from the layman. John Baldwin, in his book Contemporary Sculpture Techniques identifies this ability when he cites from Sir Herbert Read: "What distinguishes the artist from the dreamer - is his plastic sensibility, his capability in manipulating materials, above all, his sense of form." ${ }^{1}$

A sculptor's choice of media, tools, and methods of working cannot be separated from the creative process. Both his form and his technical means of achieving that form must crystalize together. The English sculptor Henry Moore sumnarizes the factors involved in the creative process of sculpture as follows:

Each sculptor through his past experiences, through obser-

1

John Baldwin, Contemporary Sculpture Techniques (New York: Reinhold, 1967), p. 9 . 
vation of natural laws, through criticism of his own work and other sculpture, through his own character and psychoiogical make-up and according to his stage of development, finds that certair qualities in sculpture become of fundanjental importance to him. 2

The problem then becomes one of leading and encouraging the adolescent student to explore sculpture as a form of art through the process of experience with his tools, materials, and techniques. I will attempt to accomplish this through the indirect method of sculpture using the solid casting process. My purpose is to study the feasibility of teaching the adolescent student the indirect method of scuipture using the multiple-piece plaster mold as a means of casting in aluminum and concrete. Solid casting is to be viewed as a means of further expanding his positive and negative concepts of form.

The focus is confined to a group of eighteen second-year crafts students at Medford Mid-High School ranging in age from fifteen to sixteen years. They are a select group in that they have elected to take this second year crafts class. All classes in the crafts area at Medford Mid High are elective and taught on the exploratory approach to learning. There exists a balance between the experimental and furidamental learning methods. The fundamental approach invclves the students' learning the design elements of line, form, color, texture, space, and light. In addition, they are introduced to the principles of design: harmony, function, emphasis, variation, proportion, balance, rhythm, and repetition. The experimental approach places emphasis on the individual student learning through personal involvement and discovery.

2

Henry Moore, HENRY MOORE: Sculpture and Drawings 1921-1948, Ed, . David Sylvester, (London: Percy Lund Humphries, 1957), I, 30. 
The goal of the program is to provide the student with a creative means of problem solving. In his first year (freshman or sophomore) the student investigates these fundamentais and grows through contact with a variety of tools, materials, and processes in the areas of ceramics, bookbinding, sculpture (direct), jewelry, leather, and weaving. In the course of the second year's study (sophomore), the student explores ceramics through slip casting and glaze formulation. He is given casting experience in the lost wax process of jewelry making. Jewelry is followed by enameling, and sculpture through the investigation of the indirect casting method as proposed in this thesis. 


\section{- CHAPTER II}

A PROPOSAL FOR THE SOLUTION TO THE PROBLEM

Scuipture cannot be taught by books or the spoken word; it must be experienced by the artist. Art is command. The hands must be trained by practice, the mind by constant acquisitions of knowledge, and the heart by its undefeated faith and desire to overcome all obstacies. For scuipture is a thorny road beset by barriers, defeats, and disappointment.s. 3

- This quotation from the sculptor Malvina Hoffman expresses the approach which I take in teaching sculpture. The process of sculpture must be experienced to be learned. Boris Blai, Director of Art at Temple University, remarks: ". . experience is knowledge: to accept the opinion of others without awareness is ignorance, waste, ard imitation." 4 Form comes to fruition as a result of direct personal involvement with materials, implements, and processes. The creation of significant sculpture is not possible without knowledge and control of technique, abijity with tools, and use of materials.

The preceding statement supports my validation for the use of plaster molds and solid casting of aluminum and concrete. It is my premise that the student can best learn by being given an opportunity for actually casting into a mold in either aluminum or concrete.

In support of this major premise, there exist a number of minor

3Malvina Hoffman, Sculpture Inside and Out (New York: W. W. Norton, 1939), p. 77.

${ }^{4}$ Hoffman, p. 80 . 
but vital, hypotheses which must be put to test to substantiate the use of plaster molds for solid casting. My hypotheses are that:

1. A student's attitucie toward casting will be directly influenced by his past experiences with respect to the use of materials, tools, and techniques.

2. Deperding on their quality, these past experiences will represent either benefits or hindrances to the student's success in casting.

3. The student will be capable of adapting easily to the variety of processes, media, and toois needed to complete this unit of study.

4. Casting will be of more vaiue to the student as a result of his direct invoivement and if responsibility for his success or failure rests on him.

5. There will result from casting a definite change in his understanding of concepts having to do with the relationships existing between materials, tools, and techniques of working and the effect of each of these on the creation of a sculptural form.

6. The student will have a conception of the difference between the direct and indirect methods of creating sculpture. 


\section{CHAPTER III \\ RESEARCH RELEVANT TO THE SOLUTION OF THE PROBLEM}

Before I did any research, the process of pouring molten aluminum directiy into multiple-piece plaster molds without the use of the technical processes of venting and gating of these molds remained only theory. My research supported the feasibility, safety, and artistic merit.warranting the classroom use of this casting method.

\section{USES OF PLASTER MOLDS IN INDUSTRY}

The beginning of this research exists in the industrial use of plaster molds using aluminum alloys. Industry classifies aluminum alloys into two groups:

One group includes those alloys which are not materialiy altered structurally by heat treatment, and they are used in the as-cast condition. Alloys of the other group are distinguished by marked susceptibility to improvement in their mechanical properties by heat treatment. 5

My research is directed to those aluminum alioys in the as-cast condition.

The following description taken from Heine and Rosenthal in their book Principles of Metal Casting explains the use and mixing of plaster molds in industry for casting of aluminum:

5 American Foundryman's Society, Cast Metals Handbook, 4th Ed. (Desplaines, I17inois, 1957), p. 255. 
- Casting in plaster molds, or plaster bonded molds, has become a useful casting process. Copper and aluminum base alloys may be cast in plaster molds, but ferrous alloys are not. Plaster used for molding consists of mixtures of gypsum or Plaster of Paris, $\mathrm{C}_{2} \mathrm{SO}_{4} \cdot \frac{1}{2} \mathrm{H}_{2} \mathrm{O}$, and ingredients such as talc, asbestos fiber, sifica flour, and others to control the contraction characteristics of the mold and setting time. The plaster is added to water and mixed to a consistency of 140 to 180 . Consistency is defined as the pounds of water per $100 \mathrm{lbs}$. of plaster in the mixture. Dry strength of the plaster depends greatiy on the consistency of the mix. After mixing, plaster in a creamy condition is poured over the pattern in a flask. A pattern parting, stearic acid disolved in petroleum spirits, for example, may be used. Generally metal patterns are necessary because the water in the plaster raises the grain on wood patterns and makes them almost impossible to draw. After setting 20 to 30 minutes, the pattern can be rapped and blown off the mold by air. Permeable (porous) casting plaster can be made by beating air bubbles into the plaster slurry with a mechanical mixer. Permeabilities up to 130 in standard permeability tests are possible. (See Table II) Setting of the plaster involves hydration of the gypsum: $\mathrm{C}_{2} \mathrm{SO}_{4} \cdot \frac{1}{2}+3 / 2 \mathrm{H}_{2} \mathrm{O}=\mathrm{C}_{3} \mathrm{SO}_{4} \cdot 2 \mathrm{H}_{2} \mathrm{O}+$ Heat. After setting, the molds are dried at $4000 \mathrm{~F}$ or higher. For aluminum castings, 10 to 20 hours at $400^{\circ} \mathrm{F}$ is suitable. The plaster can be partially dehydrated at higher drying temperature, and consequently the mold evolves less steam when the castings are poured. However, mold strength is lost when dehydration occurs. 6

For a breakdown of the various ratios of the dry strength of plaster and water content see Táble I, p. 9 .

One of the problems with which industry is concerned is that of hydrogen control. The presence of hydrogen in aluminum castings is the cause of many faulty castings and may be due to a number of different factors. Soine of these are listed below:

... hydrogen in the melt is a reaction product of a) uminum and water vapor introduced into the melting system, either with the charge, combustion products, fluxing gases, or solid salt fluxes. Because the

6Richard W. Heine and Philip C. Rosenthal, Principles of Metal Casting (New York: McGraw Hi11, 1955), p. 41. 
reaction is accelerated with increasing temperatures, the melt should not be overheated.

Overheating melted aluminum may result in surface pin holing as well as a porosity problem, therefore, ". . the pouring temperature should be the lowest temperature at which the moid can be filled without danger of misruns and cold shuts." 8

${ }^{7}$ Aluminum Company of America, Aluminum: Fabrication and Finishing (Metals Park: American Society for Metal, 1967), III, 31.

8Douglas Brown Hobbs, Working with Aluminum. (Milwaukee: Bruce, 1947), p. 21. 


\section{TABLE I}

\section{DRY STRENGTH OF PLASTER AS DETERMINED \\ BY CONSISTENCY OF FLASTER}

Dry Compression Strength

(Pounds Per Square Inchi)

11,000

6,000

4,000

2,000

200
Consistency, Pounds of Water

Per 100 Pounds Mix

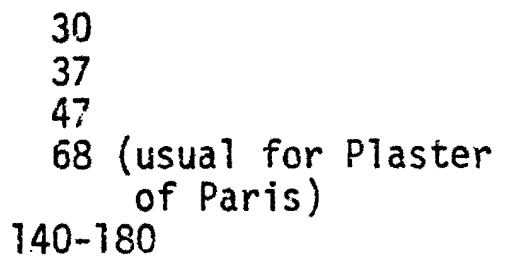

30

37

47

68 (usual for Plaster

$140-180$

${ }^{9}$ Heine and Rosenthal, p. 41. 


\section{TABLE II}

\section{STANDARD PERMEABILITY 10}

Standard permeability is determined by measuring the time necessary for $2000 \mathrm{cu} \mathrm{cm}$ of air to pass through the standard specimen while it is confined in the specimen tube and under a pressure of $10 \mathrm{~g}$ per $\mathrm{sq} \mathrm{cm}$. If the time has been cetermined, the permeability number, defined as the rate in cubic centimenters per minute which will pass through a sand volume $1 \mathrm{sq} \mathrm{cm}$ in cross section and $1 \mathrm{~cm}$ high under a pressure of $10 \mathrm{~g}$ per sq $\mathrm{cm}$, can be calculated from the following formula: $P=\frac{V H}{P A T}$

Where $V=$ Vol. air $2,000 \mathrm{cu} \mathrm{cm}$

$H=$ Height of sand specimen $=2.0$ in by $2.54 \mathrm{~cm} / \mathrm{in} .=5.08 \mathrm{~cm}$ $P=$ Fressure $=10 \mathrm{~g} / \mathrm{sq} \mathrm{cm}$

$A=$ Cross-sectional area sand specimen $=1$ in. ${ }^{2} \times \pi \times 12.54 \mathrm{~cm}$ $2 / 1$ in. $^{2}$ ) $=20.268 \mathrm{sq} \mathrm{cm}$

$T=$ Time, sec, for $2,000 \mathrm{cu} c \mathrm{~cm}$ air to pass through specimen

The formula reduces to $P=\frac{3007.2}{T \text { sec }}$

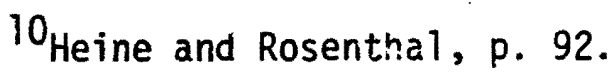




\section{RESEARCH AND EXPERIMENTATION IN CASTING IN ALIMIINUM AND CONCRETE VIA THE PLASTER MOLD}

Industrial practices using plaster, whien controlled through curing and drying of the molds and temperature coritrol, certainly suggests that classroom use of aluminum casting into plaster molds is possible. But what of the direct application to the casting of sculpture without a core, i.e., without verts and gates as used in the lost wax process? What can be expected from such a process if the procedures used by industry are applied to the casting of a metal sculpture? The answers to these questions lie in my experimentation. A series of six castings was undertaken to find the answers.

\section{Aluminum}

The following is a description of the steps involved in the formation of an experimental casting from conception through completion:

1. Creating a small form in clay.

2. Making a wire armature.

3. Forming a clay model over the armature.

4. Forming the multiple-piece mold: The number of mold pieces is determined by the number of undercuts present on the form (each undercut requires that a separate clay seam be made). Clay seams are fashioned to form coffers. Plaster is mixed with water, poured into these coffers and allowed to set. The clay seams are removed and slip is brushed onto the plaster walls to allow the various pieces of the mold to separate when the mold is completed.

5. Cleaning the mold: The mold is carefully removed from the clay and cleaned with greensoap and water. 
6. Kiln drying the mold: The mold is allowed to dry naturally for three days and placed into a kiin and dried at $400-500^{\circ} \mathrm{F}$ for four hours.

7. Securing the mold: The mold sections are secured together using rubber inner tubing. The mold cavity is then covered with paper (taped in place) to prevent foundry sand from entering the mold chamber during the packing stage.

3. Packing the mold: In this operation the mold is placed into a foundry flask with its covered cavity facing up. Foundry sand is then packed tightly around the mold until it is level with the top.

9. Removing the paper and cleaning the mold chamber: During this phase the paper is carefully removed and the foreign matter. is blown out of the chamber using foundry bellows.

10. Pouring the mietal: The aluminum is placed in a crucible inside a foundry furnace and heated until it is molten. Molten aluminum is poured at a temperature of $1100^{\circ} \mathrm{F}$.

11. Cooling the casting: The casting is allowed to cool overnight. Opening a casting too early can result in personal injury or damage to the casting.

12. Removing the casting: The mold, which has been expended in the casting process, is removed and discarded.

13. Chasing: This stage includes cleaning and finishing the surface of the casting. Any excess flashings (thin areas of metal resulting from the seams and cracks in the mold) are removed using chisels. The metal surface is then filed, cleaned with emery cloth, and buffed with abrasives, if a fine finish is desired. 
14. Applying a patina: A patina is important in providing a character and mood to the finished casting. Many media can be used for this purpose. Acrylic paint and stove black are two examples used during this series of castings.

15. Attaching the casting to a base: Since aluminum is a fairly soft metal, it can easily be drilled. Machine bolts can then be threaded into it to secure the casting permanently to a base.

This series of experimental castings reveals that the process of solid casting in aluminum is both feasible and exciting in possibilities. (See figures 4,5 , and 7, pp. 43-44.) In addition, the artistic qualities are significant; especially in the textural possibilities obtained as a result of porosity within the mold. The greater the moisture content in the mold, the greater will be the textural variation in the metal, the metal taking on a feathery quality unique to this process. (See figures 2 and 5, pp. 42-43.) Indications based on these castings reveal that chasing operations will not be any problem since the number and size of flashings resulting from this casting process are minimal.

On two separate occasions serious problems did develop which resulted in hazardous situations. In the first, a mold became misidentified as having been kiln dried. As a result, it was prepared for casting. In the process of casting, the mold, due to the moisture, exploded, blowing hot metal particies from the mold cavity into the proximity of those involved in pouring. A contemporary sculptor, Richard McDermott Miller in his book Figure Sculpture in Wax and Plaster provides the following description of the hazards of a damp mold and how this condition can be prevented: 
Doing lost wax casting in the home or studio is simple and safe, provided certain precautions are observed, as noted earlier. Before any metal is poured, the mold must be completeiy dry. A dainp mold is dangerous because molten metal will turn any moisture into steam, and steain can cause the nolten metal to erupt explosively. These eruptions can lead to ruinous defects in the finished cast and, more sericusly, to persona? injury as well. Therefore, the most inportant step in the entire lost wax process is drying out the moid. The mold used in our demonstration was air dried at normal room temperatures for a week, then heated three hours in tile oven. For the first half-hour, the oven temperature was $500^{\circ} \mathrm{F}$. As the plaster heated up, this was gradualiy reduced to $250^{\circ} \mathrm{F}$. il

On the second occasion the mold was kiln dried, and then several hours time eiapsed before casting occurred. Upon casting, the mold exploded.

It was quite apparent that the warm mold absorbed moisture from the atmosphere in the time between removal from the kiln and pouring. These two experiences point out the need for a rigid control over the drying of molds to be used for casting.

These experiences reveal that this method for small castings ranging from three to fifteen pounds is both possible and economical for classroom purposes. Larger castings, such as figure 5, p. 43, are possible through this process, but are not economical. These larger castings might prove more economical if cast in concrete.

\section{Concrete}

Since the processes involved in mold formation and cleaning are the same for both aluminum and concrete, the only problem is one of becoming familiar with concrete. This is made considerably easier by experimentation following the direction of John Mills in his book

11 Richard McDermott Miller, Figure Sculpture in Wax and Plaster Ed. Gloria Bley Miller (New York: Watson Gupti1, 1971), p. 144. 
Sculpture in Concrete. 12

Concrete requires different methods, toois, and materials in the forming of a casting than does aluminum. This introduces an entirely new series of problems and possibilities through the use of the multiplepiece mold. The casting formed as a result of using concrete is dependent upon a mixing of water and concrete in the correct proportions. After mixing, the concrete is allowed to set, harden and cure. These three stages are often confused; therefore, the differences should be noted. Mills clearly defines the processes and their differences as follows:

When water is added to the concrete mix the process of hydration begins, causing the cement to solidify and bind the aggregate. The initial change from a fluid to a solid condition is known as the, setting, not to be confused with hardening which is the strength development time, after setting. Curing is the period of maintaining the development of strength in the solid, by prolonging favorable conditions. Hardening, and therefore curing, will cease as the solid dries out. Proper cure will depend upon the retention of moisture in the concrete. The development of strength in the solid concrete goes on indefinitely if conditions are favoräble. 3

Below is a description of a process which I use to form a casting in concrete:

The mold pieces still damp, are coated with an engine oil lubricant brushed on the inner surfaces. When the lubricant has been applied, the pieces are secured together with rubber inner tubing and twine. Metal rods are fashioned and carefully fitted into the cavity of the mold. The mold is shimmed so that the cavity is in a position which will allow the 1968).

12John W. Mills, Sculpture in Concrete (London: MacLaren and Sons, 13 Mi11s, p. 22. 
cement to be poured and tamped into it without movement. A Portland cement $(2$ parts) is dry mixed with vermiculite as an aggregate material (1 part) in a plastic mixing tub. Water is added to the dry mix gradually, using the hands and a small hand trowel, until a workable consistency of thick paste is obtained. When the mixture is of the correct consistency, the cement is poured into the mold cavity around the metai rods and carefully tamped into place with a small hand tamping tool. The casting is then wrapped in damp cloths and left to set and harden. It is allowed to harden and kept damp for three days. The mold is then carefully removed. After the lines formed by the mold seams are carefully removed with a knife, the casting is left to cure for several more days. This is followed by a cleaning with a muriatic acid and water solution (one part acid to three parts water) brushed onto the surface. The casting is then left to cure for three weeks.

\section{STUDENT QUESTIONNAIRE}

Having established the plausibility of using plaster molds to cast in aluminum and concrete, it is necessary to ascertain whether this group of students is capable of undertaking the solid casting process. A questionnaire is designed with which to obtain information on the individual student's background, interests, and abilities in sculpture. (For a complete breakdown on responses to the questionnaire by specific categories, see the Appendix.)

What follows represents the conciusions based upon the responses of the eighteen students invalved in this study to the questionnaire on sculpture. This questionnaire is filled out prior to beginning the 
casting experience. The information summarized here and gathered in the appendix is only reflective of the preferences, attitudes, experiences, and sources of influences peculiar to the nembers of this particular group. Generalizations cannot be taken to be representative of other groups.

I find that the vast majority of these students has some form of sculpture at their nomss. Their greatest contact with sculpture is with public and private monuments. Art galleries represent an influence for only half of them. Fow indicate having any opporturity to sculpt outside the classroom. They cite their teachers as being their major source of encouragement, while the home is $f \in 1 t$ to be an insignificant source of encouragement. The majority claims prior experience in sculpture. These experiences are varied with wood, plaster, and clay being the materials most frequently indicated.

Most students associate sculpture with mental and physical effort, emotional involvement, and technical problem solving. A majority feels that sculpture is dependent upon both the visual and tactile senses.

Group members grasp the idea of the additive and subtractive approaches to sculpture though they seem to have a low comprehension of the direct and indirect methods of creating sculpture.

The majority of this group knows something of those tools having to do with the modeling of clay and the carving of wood though not with those tools used for working with metal.

These students appear to be familiar with the structural characteristics of those materials with which they have had prior contact. Similar$1 y$, they have no knowledge of the structural characteristics of those 
materials with which they lack any previous contact. This conclusion is borne out in the fact that most of the students indicate $\partial$ belief that both clay and aluminum require the use of an armature. There is also present a definite ambiguity concerning the sculptural relationships of form and space. While most of the students are able to identify the terms of form and space as factors being involved in the sculptor's ability to conceive reality, they lack any definite comprehension as to what ideas these terms express.

Their ability to express the belief that there is an advantage to the making of a sculptural mold reflects their past experiences with making multiple-piece molds for ceramic slip castings. They are able to understand the concept of casting but are unfamiliar with the application of casting in metal and concrete.

It is quite evident that prior contact with tools, media, and methods plays a very significant and essential role in the formation of abilities, attitudes, preferences, and the understanding of sculptural concepts. All learning is not the result. of direct process learning. A great deal comes to the studert indirectly through asscciation with peers, working in other mediums, and using different too?s and techniques. This indirect learning through association seems to operate at a much more significant level than one supposes. The classroom represents the major center of the learning of sculpture in the case of this group of students. The person identified as being most influential in their understanding and creative expression of sculpture is the teacher.

'It should be concluded on the foregoing evidences that these students are ready to try the indirect process through casting in 
alumirum and concrete. Their unfamiliarity with respect to the use of tools and techniques used for casting in these two materials indicates a need for contact. The fact that they possess a good background in those materials, tools, and processes with which they have had prior experience gives credence to their ability to learn.

Thus, I now turn to testing the theory of the adolescent's ability to cast in aluminum and concrete via the plaster piece mold. 


\section{- chapter iV}

\section{METHODS AND TECHNIQUES}

\section{UNIT INTRODUCTION}

The students are introduced to the various materials, processes, and tools necessary to the indirect method of forming sculpture. Using a series of slides, I iliustrate how the use of the mu?tiple-piece mold allows for the transferring of an original clay form into a more permanent material. The students are told that they have a choice of either aluminum or concrete as their permanent material for a casting. The completed casting is to be determined by a series of sequential stages. These stages are similiar to those described in. the experimental sequences used for solid casting in aluminum and concrete: (See pp. 1116.)

1. Creating a clay model

2. Forming a wire armature

3. Modeling a clay form

4. Making a mold

5. Preparing a mold for casting

6. Casting

7. Chasing

8. Applying the patina

9. Mounting the completed casting 
At the beginning of each stage, the group is provided with a cemonstration and instructed to solve that stage as a separate problem. What follows is a description of each stage as a presented problem and evaluation of the ability of the group to solve it.

\section{PHASES OF CASTING AS PROPOSED PROBLEMS}

\section{Probiem 1: Creating a Clay Form}

Method of Introducing the Clay Form. The need for simplification of forms into their most essential parts and the emphasizing of these to obtain unity is discussed and illustrated. Possible sources of sculptural ideas are presented along with the effects of material, technique, and tools. Animal forms are introduced due to the simplification of these forms as they exist in nature. The group is then given a demonstration in clay modeling and left to solve the problem on an individual basis. Evaluation of Problem 1. This stage was not found to present any problems as all the students had previous contact with clay. They were - able to account for the plastic and structural characteristics of clay. The major subject matter centered around human and animal forms as suggested by me. These forms proved easily adaptable to clay material. The fact that several students had preceded the group through this stage and were now forming their molds proved to be advantageous. This enabled the majority of the students to grasp the need for simplification of their forms.

\section{Problem 2: Construction of an Armature}

Method for Forming an Armature. The construction of an armature requires that the student be able to form a wire armature by brasing it 
sogether using an acetylene torch and brasing rod. is technical problems are anticipated since the students have previously used this equipment in the forming of jeweiry.

Evaluation of Problem 2. The construction of a wire armature did not represent a problem. The anount of assistance required was negligible. Evidence suggests that the lack of problems during this stage can be directly attributed to past experience with the equiprnent.

Problem 3: Modeling of a Clay Form Over an Armature.

Method of Forming the Clay Over an Armature. This problem requires that the student perform essentially the same processes as he did during problem one. The only. exception is that he apply the clay over the armature and then complete the modeling of the form.

Evaluation of Problem 3. During this stage the students encountered few difficulties with the material characteristics of clay. A problem did arise, however, with the conception of the sculptural relationships existing between form and space. This was clearly illustrated both by the verbal comments made by many students and their clay forms. It is worth noting that this problem did not arise during problem one. This can probably be attributed to the fact that the first clay sketches were smaller and less interest was attached.

This problem was overcome by advice and information from two sources. First, I advised the students that they continually move their clay forms and work on them as total structures. The second influence was again provided by those two students involved in forming their molds. As in problem one, they were expressing a need for simplification of form. In addition they were verifying the necessity of working on the 
entire clay form as a total unit. Those students stili modeling vere able to assimilate the experiences of these two students. This assimilation process became both a positive and a significant factor in student success during this stage.

\section{Problem 4: Forming the Piaster Piece Mold}

Description of the Mold Making Process. Solution of this problem requires the student to evaluate the number of mold pieces as determined by the clay form. Each urdercut cccurring on the surface of the form requires fashicining a clay wall or seam about one and one-half to two inches high and a quarter inch thick. By sticking these strips on the surface of the clay model, the student forms coffers in which to pour the mixed plaster. After these walls are in place, the plaster is mixed and poured into them. When the plaster has set, the clay strips are removed and the plaster walls cleaned. The clay seams forming the coffers for the next mold sections are covered by clay slip brushed onto the wall surfaces. The plaster is again mixed and poured. This process is repeated until the entire mold is formed about the clay model.

Evaluation of Problem 4. The uniqueness of this process of fashioning a piece mold proved to be challenging for some students and frustrating to others. The ability of students to solve this problem developed slowly. A number of students had to become familiar and adept before the less venture-some students would uridertake the problem. Once this problem was overcome this stage moved smoothly. It is quite evident that group solutions and learning by assimilation were responsible for student success. 
Probiem 5: Preparing the Mold for Casting.

The processes to be used by the students in preparing their moid for casting are the same as those described and used in experimentation with aluminum and concrete. (For a detailed description of these two processes, see ATuminum pp. 11-i3 and Concrete pp. 15-16.)

Evaluation of Problem 5. This problem, while requiring a number of separate operations, did not present any notable obstacles. I insured against the possibility of damp molds entering the foundry by controlling the drying of the molds to be used for casting aluminum. Several students experienced having their molds break up upon removal from the kiln. This situation was corrected by dipping burlap strips into plaster and placing these across the broken sections of the mold. Once the students had a mold prepared they became quite anxious to get on with the casting operation.

Problem 6: Casting Process as Determined by the Material Selected for Casting.

The students were given a choice between aluminum and concrete from which to make their final casting. Fourteen of the seventeen students successfully completing a casting, seiected aluminum as their material. The remaining students seiected concrete. The one unsuccessful student had a severe attendance problem.

Aluminum: Description of the Casting Process. The students are introduced to the casting operations when several are ready to cast. I explain the processes involved in casting, i.e., use of the furnace to heat the metal, the crucible as a container for melting and holding the molten metal, and the process of pouring the aluminum into the molds. I 
also emphasize the need for safety. The students are then encouraged to lnok into the furnace during the meiting process. When the metal is prepared, they are able to watch the metal art students, who are familiar with the sand casting operation, pour the molten metal into their molds. The following day, after conling, the castings are removed from the molds and cleaned with a wire brush.

Evaluation of Casting in Aluminum. Safe casting necessitated that the pouring be done by students familiar with metal casting; hence, the crafts students became spectators. Both these students and the foundry students were introduced to a new process of casting, and the crafts students were able to identify with some of the processes and equipment used in the foundry.

Concrete: Description of the Process Used by the Student. The processes demonstrated to and used by the students for casting in concrete are the same as those described in the experimental investigation of concrete casting. (See pp. 15 and 16.)

Evaluation of Concrete Casting. The three students who selected concrete were quite enthusiastic about the process of casting and the results. It was much easier for the students working in concrete to complete their castings than those casting in metal. This was due to the nature of the material, the tools used, and the relatively inexpensive equipment. Of these two materials, concrete lends itself to classroom use much more readily than does aluminum. Aluminum, however, is much more popular.

It should be noted that casting in concrete allows the student to make repeated castings, as the mold is not destroyed during the casting 
process. Two students took advantage of this characteristic and used their molds for making a second casting.

\section{Problem 7: Chasing}

Description of the Chasing Process. It is necessary for the student to clean the surface of the resulting casting in both the aluminum and concrete. The method of chasing is to be determined by the material used to form the casting.

Aluminum. It is necessary for the student choosing aluminum to employ chisels, files, and wire brushes for cleaning the surface of the aluminum. First, he is to remove the flashing resulting from the seams of the piece mold. Once this is removed, the surface is cleaned with a wire brush to remove the mold material. Cleaning is followed by a filing of the surface. Since aluminum is such a soft metal, single cut files are used, as they are less likely to clog. Filing is followed by machining with a wire rotary brush and the use of emery cloth, if a satin finish is desired. In those cases where a finer finish is desired, a tripcli abrasive and polishing wheels can be used. The students are instructed not to grind the aluminum on a grinder as this will clog the grinding wheel.

Evaluation of Aiuminum Chasing. The resulting surface quality obtained in aluminum was readily acceptable to those students selecting it. Initially, few studerts expressed any desire to have a highly polished surface. This desire was quickly changed after they began chasing. Though there was aluminum filler available with which to alter the surface, only one student resorted to using it. They appeared quite capable of performing the necessary chasing operations. 
Chasing of Concrete. Those students seiecting concrete are to use different procedures and tools for chasing than those using aluminum. rollowing the removal of the casting from the mold, the ridges left by the mold seams are remcved witin a paring knife. The surface is then cleaned with a wire brush. Muriatic acid (one part acid to three parts water) is then appiied as a cleaning agent. Following the cleaning it is explained to the students that curing of the concrete will continue for about three weeks from the time of the cleaning. At the end of this period of time the maximum strength is obtained in the concrete.

Evaluation of Concrete Chasing. The three students choosing to use concrete proved themselves capable of chasing the concrete. All were aware of the texture obtained as a result of the mixing of concrete and vermiculite. Evidence revealed that the use of acid did not represent a problem with the small number of students using it. Had more students cast in concrete, the safety factor would certainly have increased.

\section{Problem 8: Applying a Patina.}

The function of a patina is described to the students as being instrumental in providing the final effect of color to the surface of the completed casting. A patina is important, as it relates the surface of a sculpture to its central mood. The final color and texture of a particular sculpture is determined by the choice of materials and taste of the sculptor.

Aluminum Patinas. The students are encouraged to experiment with paint as a source of aluminum patinas, as suggested by Mills in the following statement: 
Personal!y I have found that attractive patinas can be best achieved on aluminum by using paint. Any colour can be applied. Further, if when the paint has dried, you rub through this with wire wool to reveal the metal, then polish that metal with a metal polish and very fine wet and dry emery cloths, a very attractive patina can be achieved. The metal polish leaves a deposit in hollows which can be brushed out if not wanted. The resulting patina, made in this way, is often much richer and more dense than can be achieved on aluminum in other ways.

The patina can be fixed with a lacquer or resin application. 14

Another patina which I have used on aluminum is stove black. It is very inexpensive and can be applied simply with a cloth to the metal and then the raised surfaces cieaned with steel wool or emery cloth. A wax or lacquer finish may then be appiied to protect the surface.

Evaluation of the Use of Aluminum Patiras. Those students choosing to cast in aluminum selected acrylic paint as the major source of a patina material. This can be attributed to the emphasis placed on safety problems associated with the treatment of aluminum with acids. I do not feel that this choice was detrimental to the outcome of their castings. The safety of these students is better served by the use of paints as suggested by Mills.

Concrete Patinas. In working in concrete, the aggregate and concrete provide the source of the patina. A number of aggregate materials can be used to give any number of desired surfaces and colors.

Mills identifies the following as providing good effects: 15

pumice brick dust marble dust silver sand Vermiculite grog natural fine sands

of various colors

14John W. Mills, The Techniques of Sculpture (New York: Reinhold, 1967), p. 108.

15 Mills, Sculpture in Concrete, p. 23. 
The students are encouraged to evaluate the possibility of using a combination of vermiculite and concrete to create color and texture. The wire brushing and the pitting of the surface occurring from this technique is emphasized. A discussion of the various methods of obtaining different colors and textures is presented.

Evaluation of Concrete Patinas. Al1 three of the students casting in concrete selected vermiculite as an aggregate material. After their castings were completed, two of the three students commented that they would have liked to have investigated another material to obtain a different effect. All of the students were aware of the difference existing between creating patinas in concrete and in aluminum. Frequent comments were made to the effect that concrete patinas were determined during casting and could not be changed, while aluminum patinas could be renoved and changed if not desired.

Problem 9: Mounting a Completed Casting

In this final stage the students are confronted with the formation of a base which functions as a support for their completed castings. Each student is asked to consider the following factors in solving this problem:

1. What are the characteristics of his casting material?

2. What size base is required?

3. What type of rinish is needed for the base?

4. Where is the completed sculpture to be located?

5. What is the best means of securing the casting to its base?

6. What tools, materials, and methods are needed to solve this probiem? 
The forming of a base is compared to the framing of a completed painting. it is pointed out that the proper frame enhances the completed painting, functionally provides for its support, and serves to establish a point of reference. Simiiarly, the sculpture base provides support and serves to accent the scu?pture itself.

Evaluation of the Mounting of a Completed Casting. The majority of the students chcse to mount their castings on a wood base. The particular processes, tcols, and pieces of equipment did not prove to be obstacles to their completing this stage. Those students casting in aluminum were able to drill out a hole slightly smaller than the screws used to attach the base. By accounting for the softness of the aluminum they were able to screw the bases to the castings. Two of the three students casting in concrete formed their bases at the time of casting. The remaining students inserted two large machine bolts into the wet concrete during casting. The solution of the problem came as a result of a group effort. All but three of the seventeen students were able to - secure their casting to some form of base. 


\section{CHAPTER $V$}

\section{CONCLUSIONS AND RECOMMENDATIONS}

The use of the multiple-piece plaster mold as a casting vehicle for solid aluminum and concrete castings is concluded to be a rather compiex but highly challenging and broadening experience. Prior contact with tools, materials, techniques, and identification of sculptural concepts appears to play an essential and significant role in the success of this group of students.

Having students use both the concrete and aluminum simultaneousiy for casting, proved to be quite demanding. This is particularly true of the aluminum, due to the need for additional tools and equipment. A vast majority of studerts, however, selected this material as being the more popular of the two. This choice is identified by me as being due to the presentation of the unit and the connotation of permanence and mystification associated with metal casting. Concrete was found to be much more adaptabie to classroom use. It required less equipment and material expenditure and was considerably safer.

The most outstanding result of this experience was the group approach to problem solving. It is quite evident that learning by association played both an essential and significant role in the learning process. As some students learned to use particular processes and equipment, other students sought their advice. Recognition of this learning by association can be a valuable asset to the teacher. 
The following recommendations are made as a result of this experience:

1. Due to the complexity of this project, it should be presented only to students who have had prior contact with materials, tools, processes, and sculptural concepts.

2. Instructing capable students in the various stages of a project and using them as resource individuals, is a valuable aid to instruction and should be encouraged.

3. Use of both the concrete and aluminum simultaneousiy is not recommended. From an instructional standpoint, the concrete is much less demanding and safer to use.

4. It should be kept in mind that this thesis study is based on the findings of a particular group of students. A group associated with me for quite a period of time. Their prior experiences reflect those interests and background provided by me.

It is evident that the success of any unit of study will reflect the interests and strengths or weaknesses possessed by the instructor. The program and experiences can only be as good as the teacher's background and ability allow. For this reason, this study, while.valuable to myself and these students, may be quite different in another time and place. There is a definite need for more investigation into the study of casting at the adolescent level. 
SCULPTURES BY THE STUDENTS 


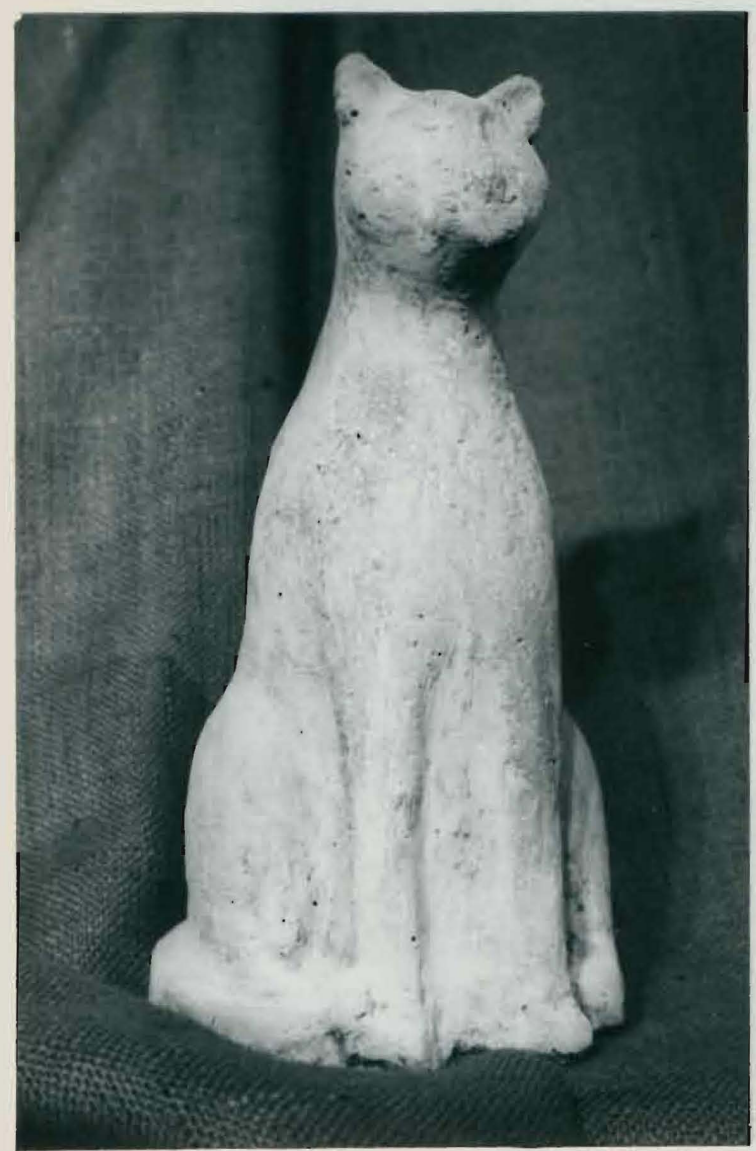

FIGURE 1. Solid Concrete

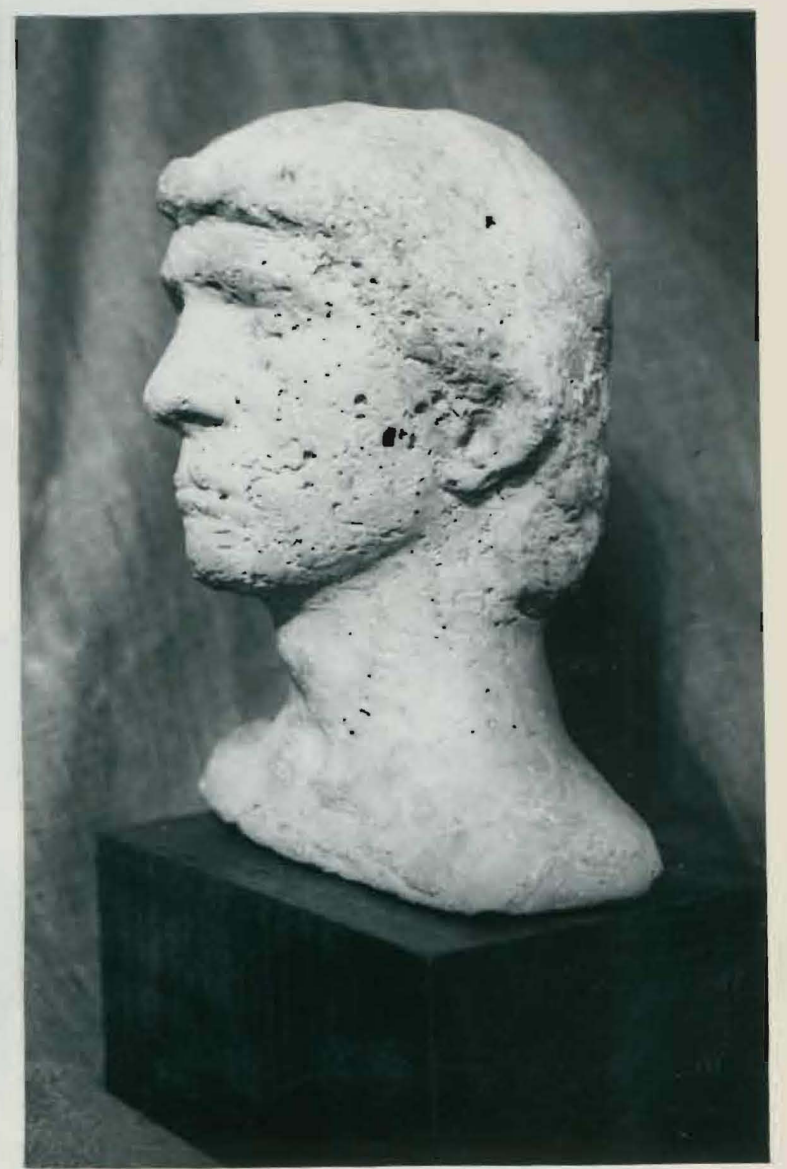

FIGURE 2. Sol id Concrete 


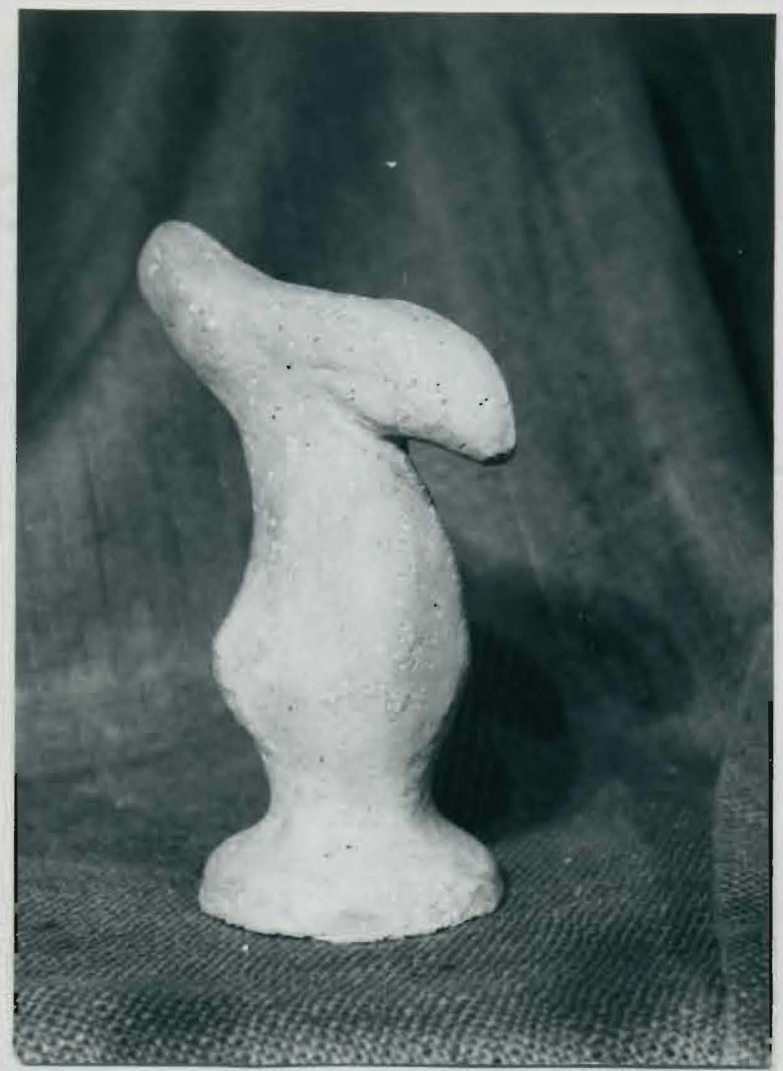

FIGURE 3. Solid Concrete

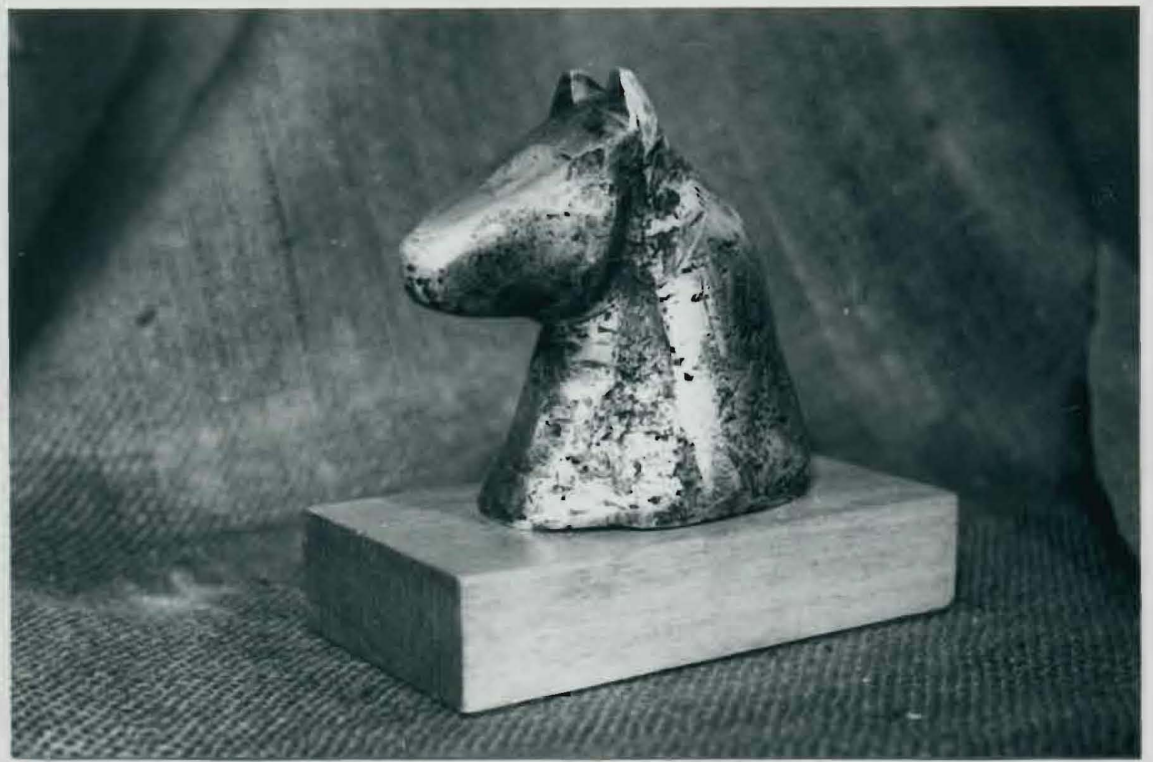

FIGURE 4. Solid Aluminum 


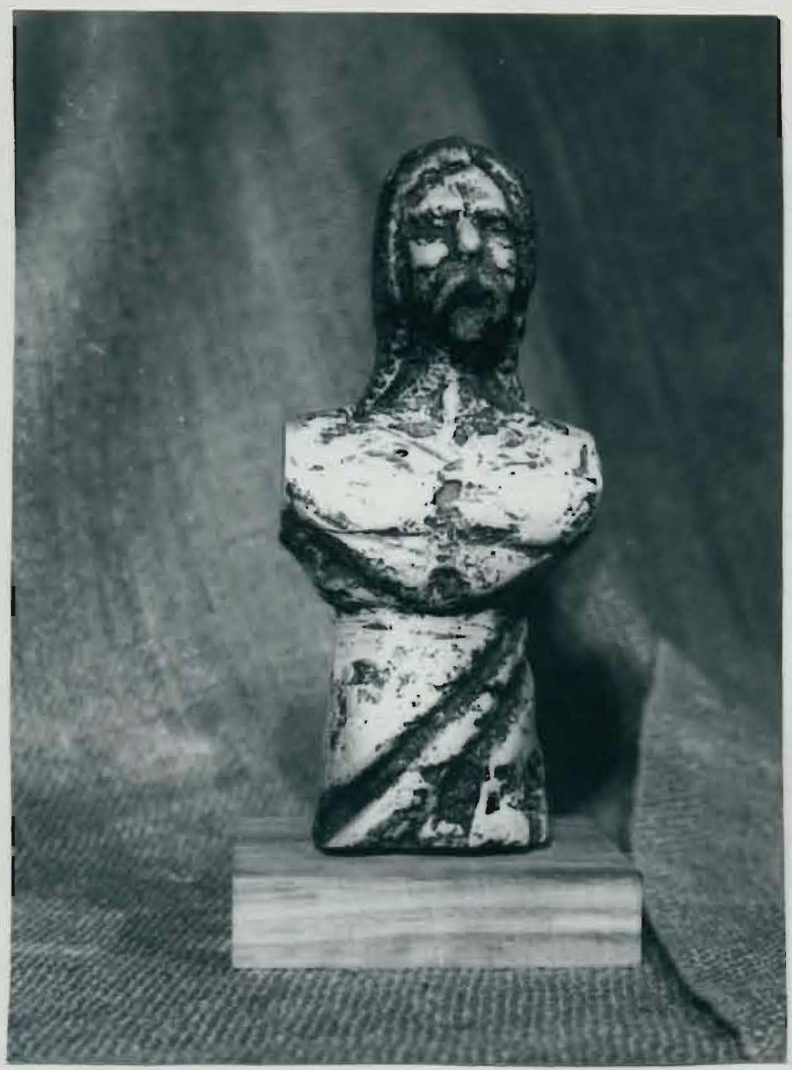

FIGURE 5. Solid Aluminum

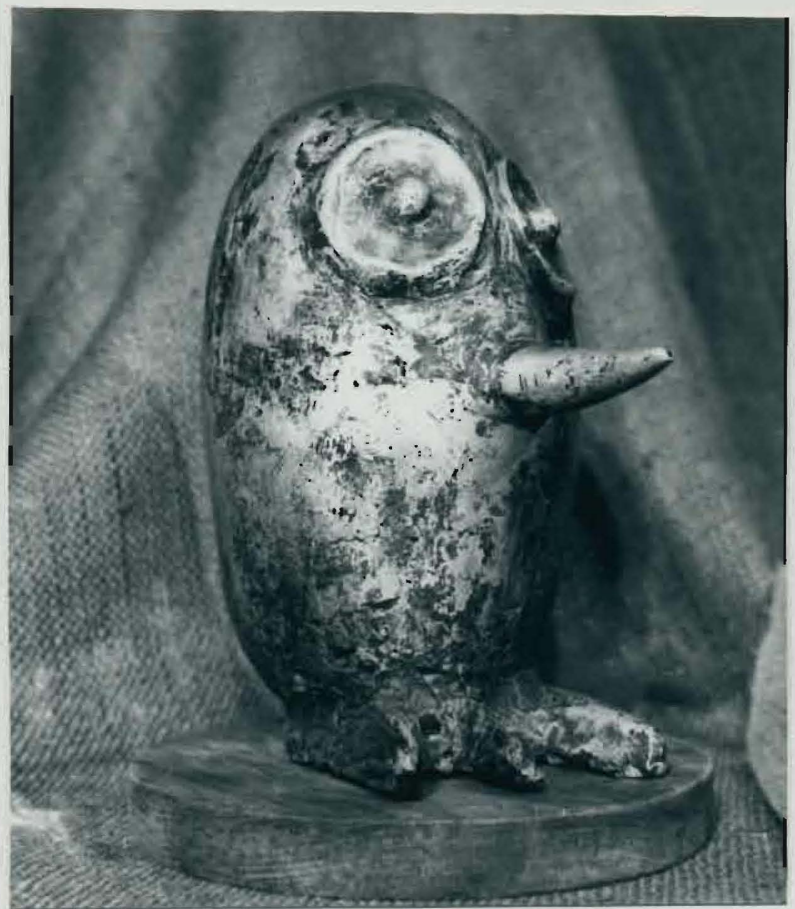

FIGURE 6. Solid Aluminum 


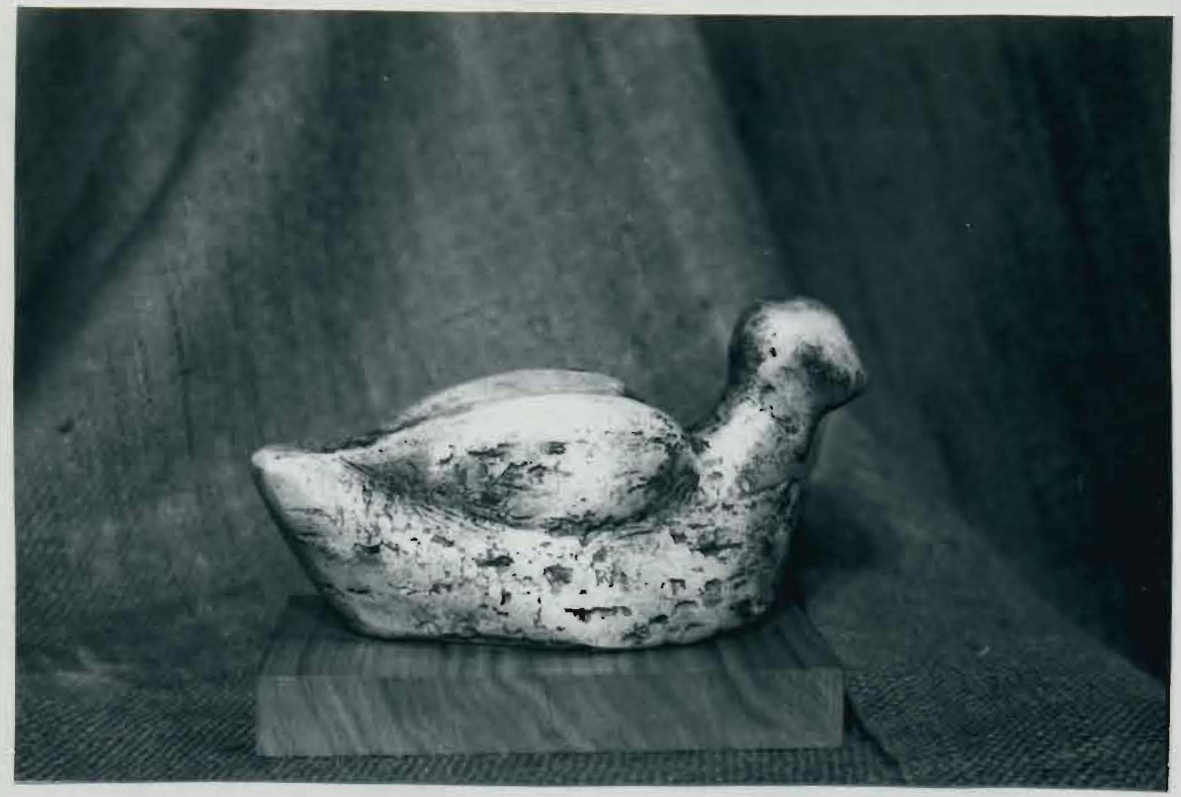

FIGURE 7. Solid Aluminum

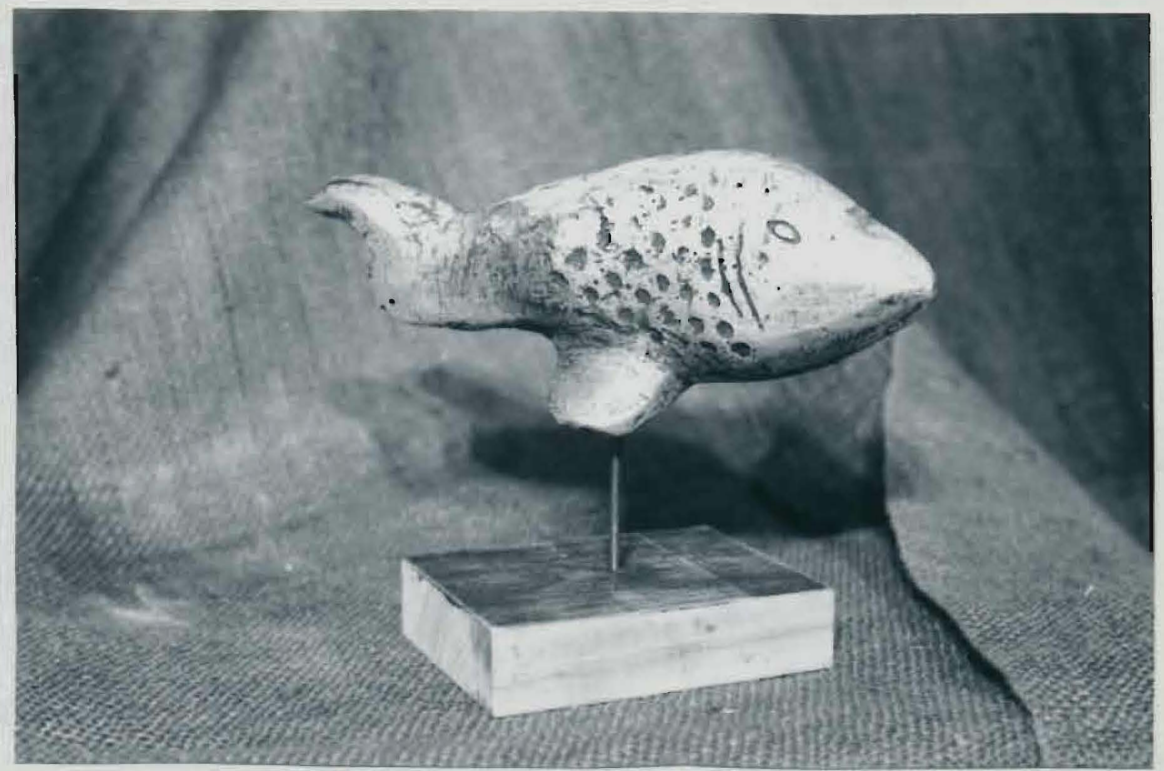

FIGURE 8. Solid Aluminum 


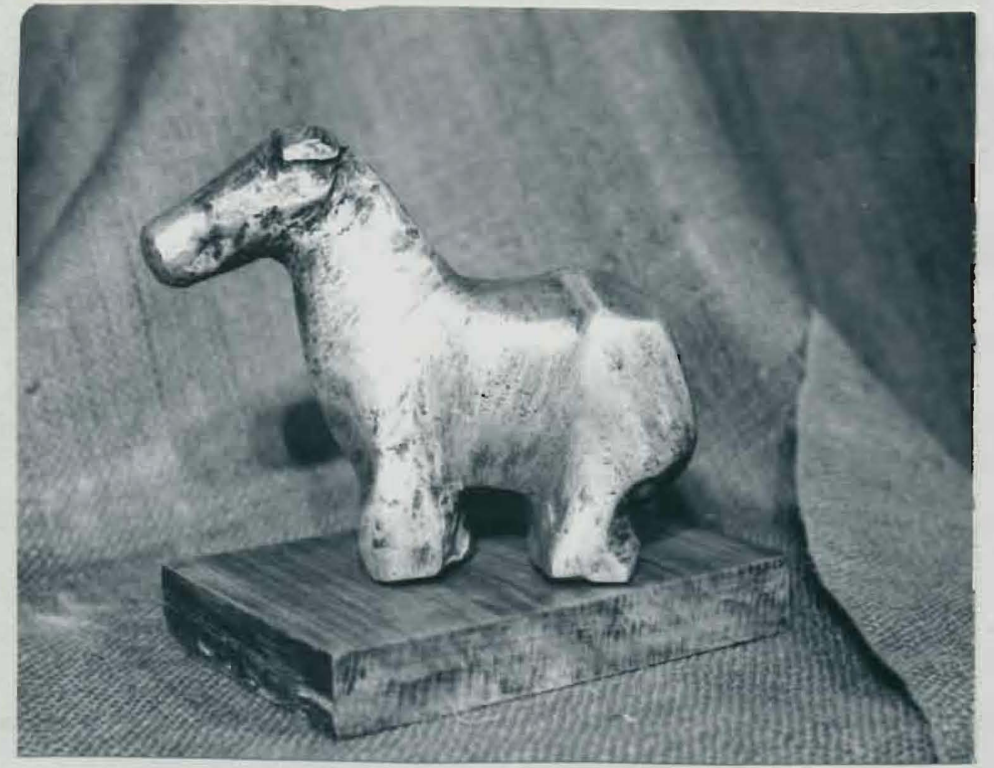

FIGURE 9. Solid Aluminum

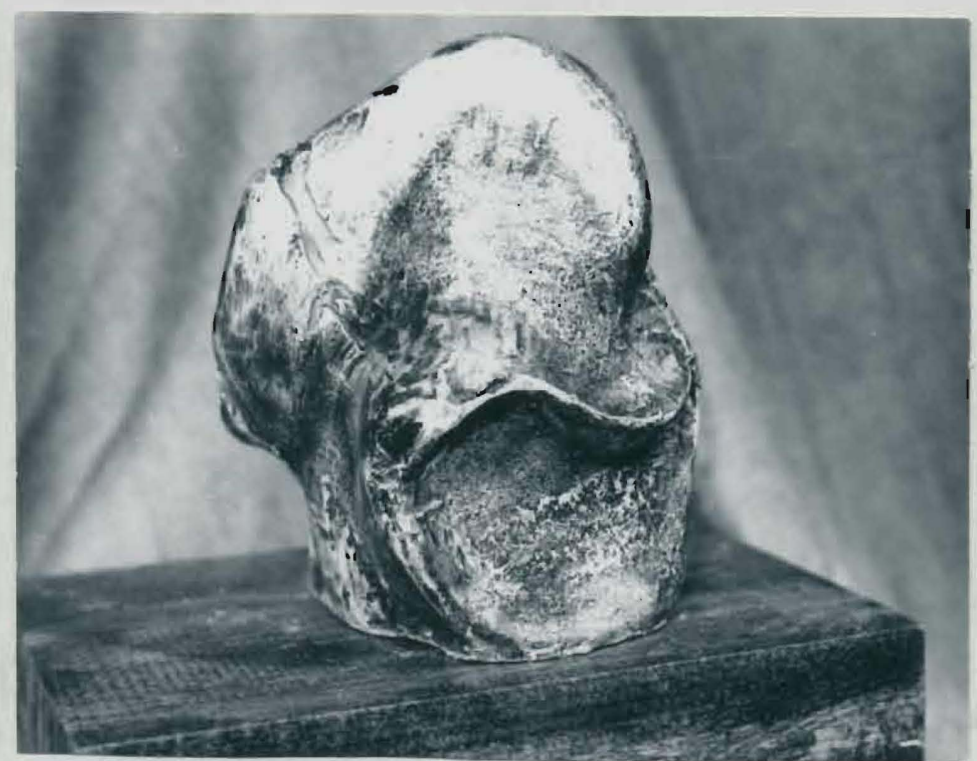

FIGURE 10. Solid Aluminum 


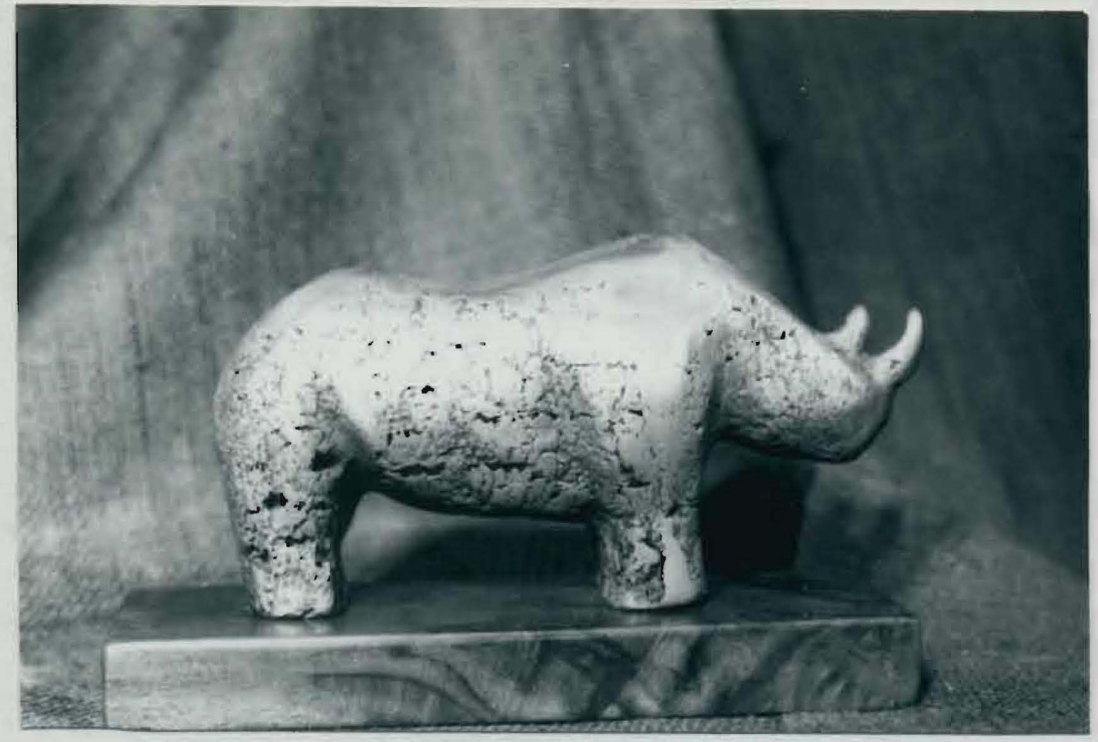

FIGURE 11. Solid Aluminum

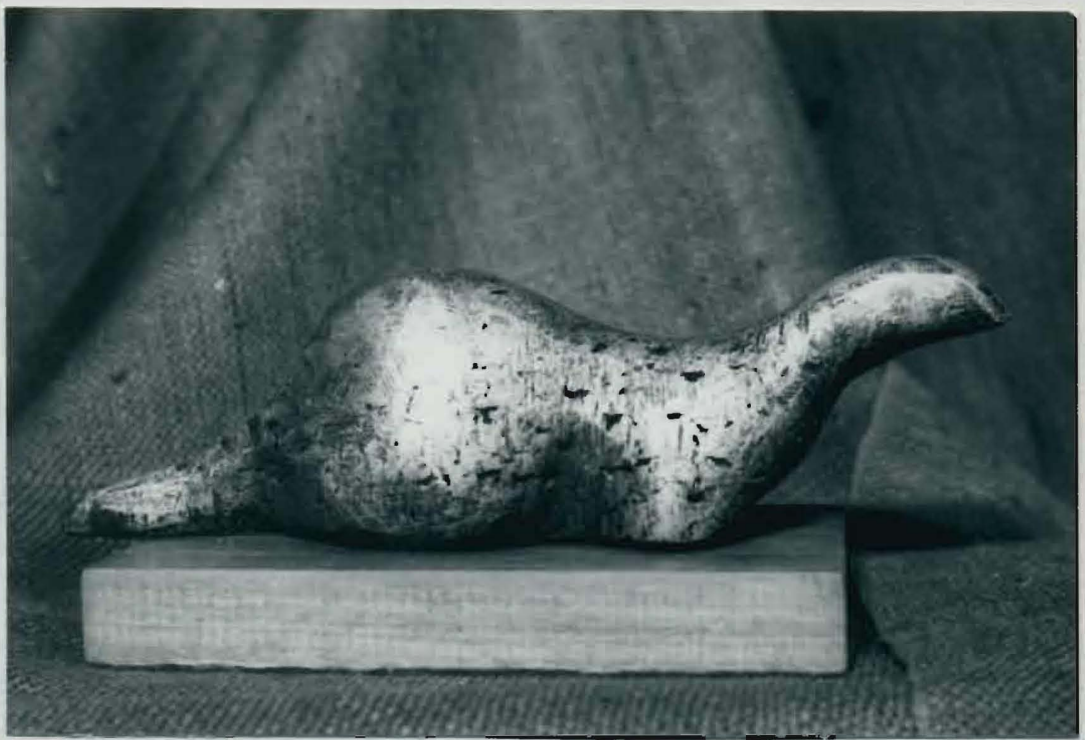

FIGURE 12. Solid Aluminum 


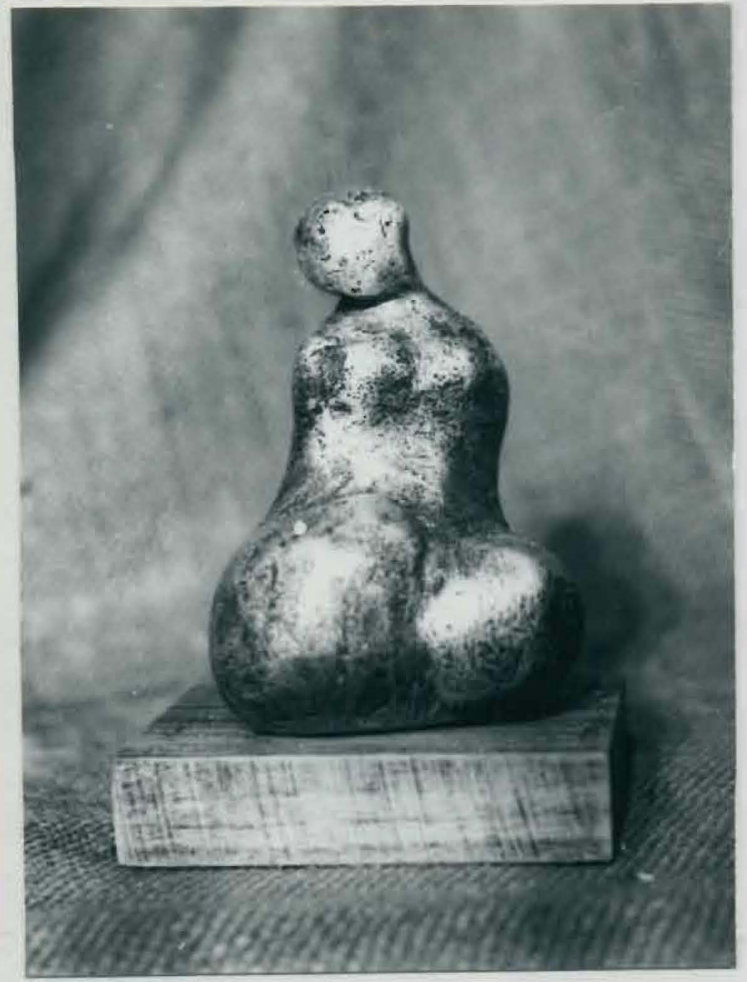

FIGURE 13. Solid Aluminum

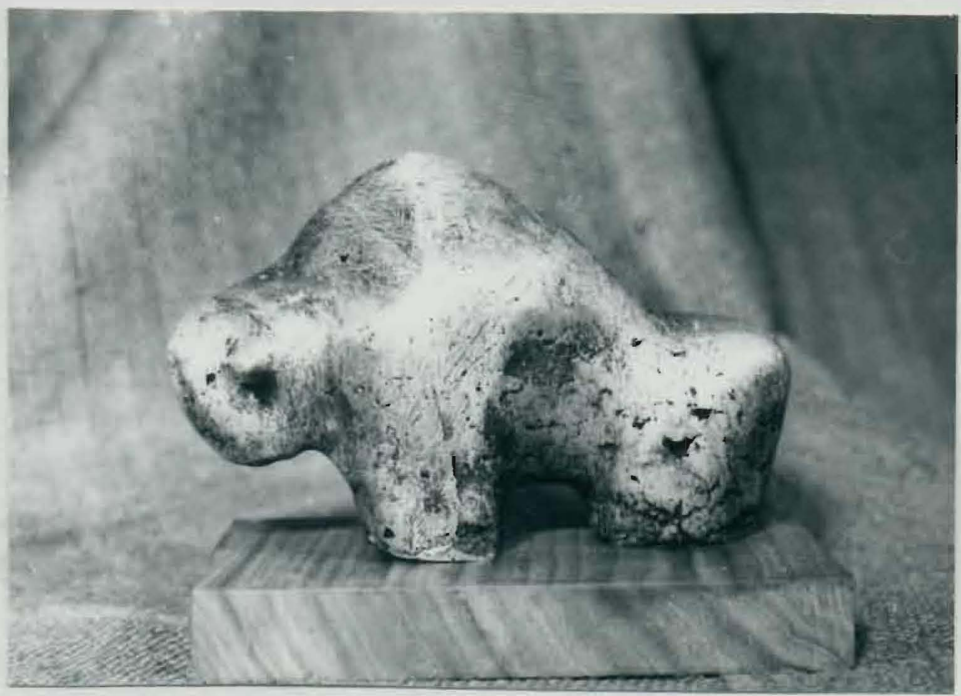

FIGURE 14. Solid Aluminum 
SCULPTURES BY THE AUTHOR 
FIGURE 1. Bronze. L. 11"
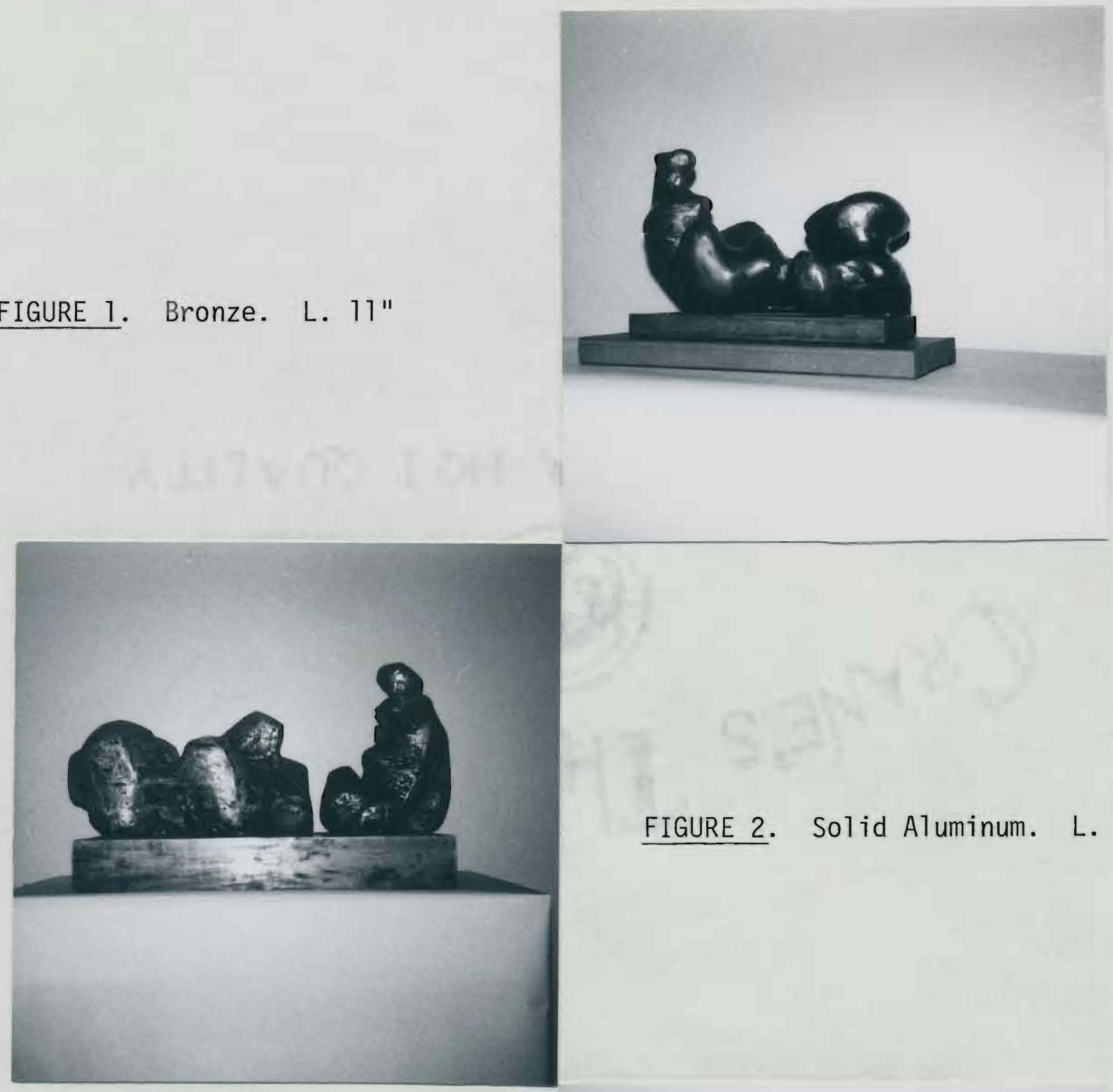

FIGURE 2. Solid Aluminum. L. 23"

FIGURE 3. Bronze. L. 17" 


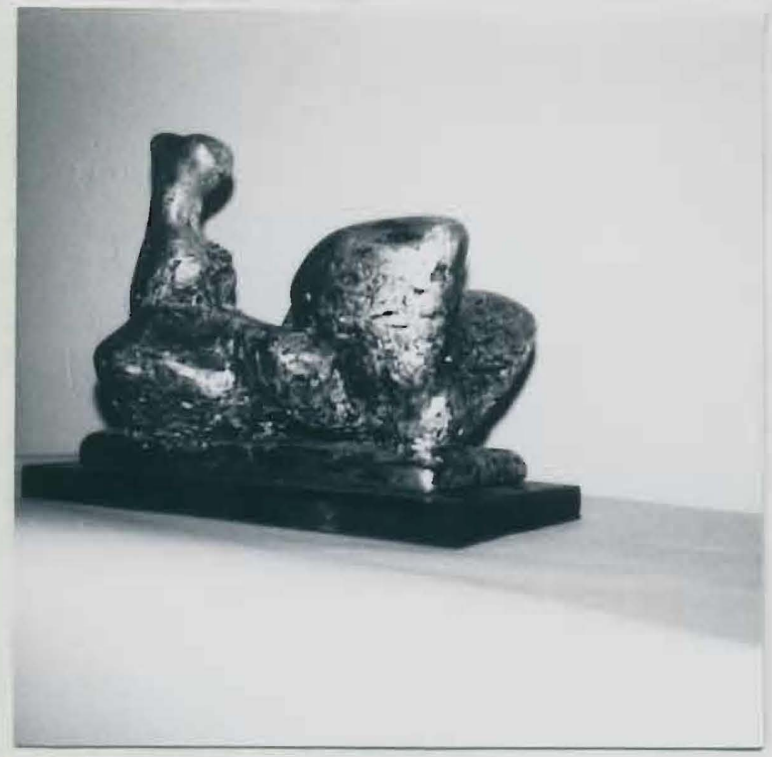

FIGURE 4. Solid Aluminum. L. 11"

FIGURE 5. Solid Aluminum. L. 18"

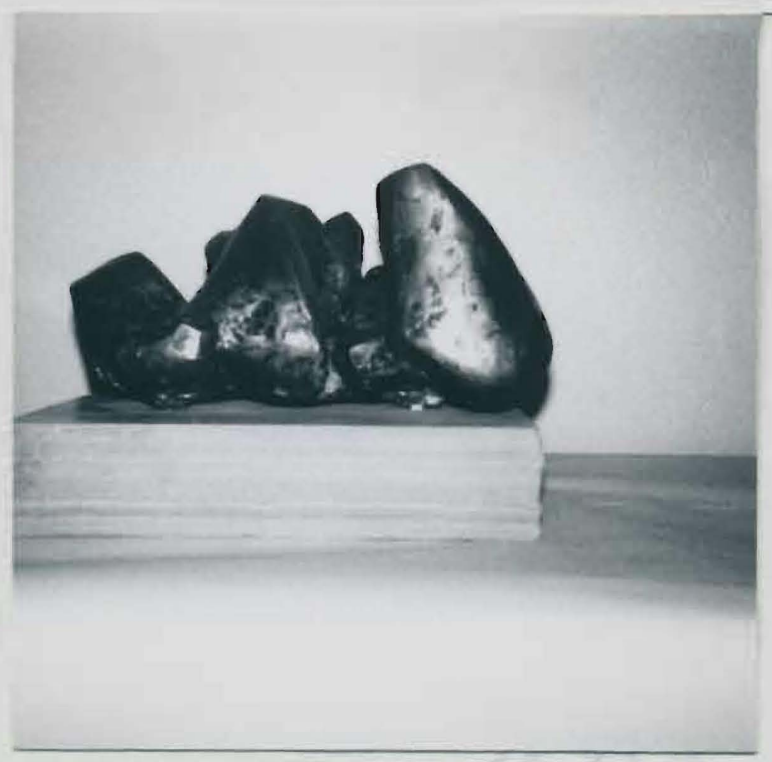

FIGURE 6. Bronze. L. 10" 
FIGURE 7. Solid Aluminum. L. 12"
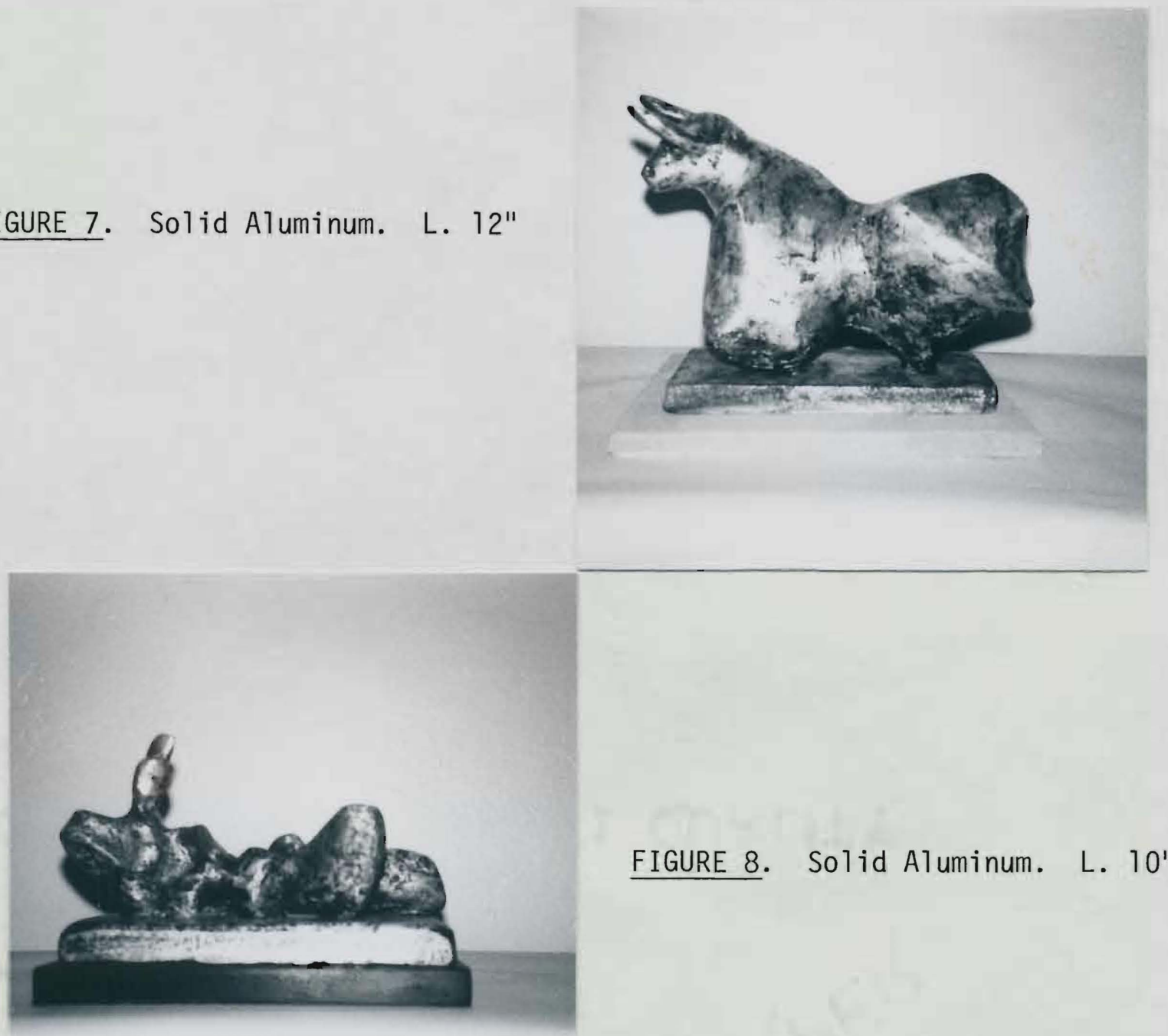

FIGURE 8. Solid Aluminum. L. 10"

FIGURE 9. Bronze. H. 26"

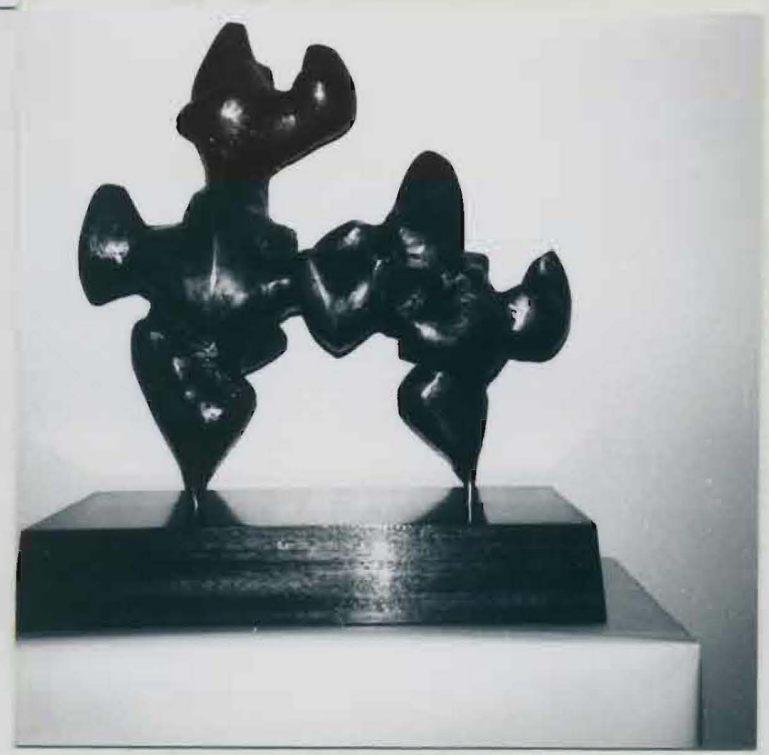




\section{A LIST OF SOURCES CITEO}

Ailuminum Company of America. Aluminum: Fabricacion and Finishing.

3 vols. Metals Park: American Society for Metals, 1967.

American Foundryman's Society. Cast Metals Handoook. 4th ed. Desplaines: American Foundryman's Society, 1957.

Ealdwin, Johri. Contemporary Sculpture Techniques. New York: Reinhold, 1967.

Campbe11, Lawerence, and Millikan, Maria. "The Crafts of Bronze Casting". Craft Horizons, 23 No. 1 (1963), 26-33.

Glickman, Maurice. "Techniques in Sculpture." American Artist, 24, No. 4 $(1960), 40-45$.

Heine, Richard $w$. and Rosenthal, Philip C. Principles of Metai Casting. New York: McGraw Hill, 1955.

Hobbs, Couglas Brown. Working with A?uminum. Milwaukee: Bruce, 1947.

Hoffman, Maivina. Sculpture Inside and Out. New York: W. W. Norton, 1939.

Miller, Richard McDermott. Figure Sculpture in Wax and Plaster. Ed. Gloria Miller. New York: Watson Gupti1, 1971.

Mills, John w. Sculpture in Concrete. London: Maclaren and Sons, 1968.

Mills, Jchn w. The Techniques of Sculpture. New York: Reinhold, 1967.

Moore, Henry S. Henry Moore: Scuipture and Drawings 192!-1948. 4th ed. Vo1. I. Ed. David Sylvester. London: Percey Lund Humphries, 1957.

Wernick, S. and Pinner, R. The Surface Treatment and Finishing of Aluminum and Its Alloy. Teddington: Draper, 1959. 


\section{APPENOIX \\ STUDEN: QUESTIONNAIRE ON SCU!PTURE}

This questionmaire las designed to iontify the attitudes, preferences, experiences, sources of influence and understanding of sculptural concepts. The findings were divided into the categories listed below. The numbers listed under each category reflect the number of the particuiar question on the questionnaire. The responses have been interpreted into percentile figures to indicate how the group of the eighteen students answered each of the various independent questions.

\section{Category I: Cultural and Social Influences Identified by Students as}

\section{Influencing the Sculpture Experience.}

1. Do you have a piece of sculpture in your home?

Yes: $83.3 \%$ No: $16.7 \%$

2. List below the following sources of experiences or contact you have had with a form of sculpture:

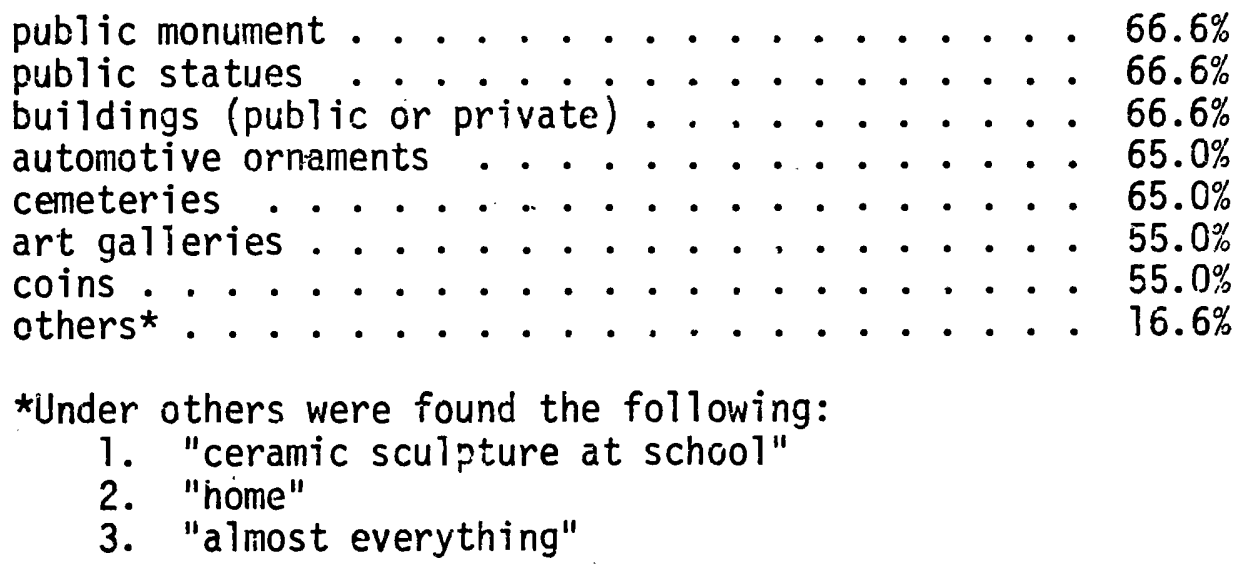


3. Do you feel the Washington Monument is an example of a piece of sculpiure or architecture?

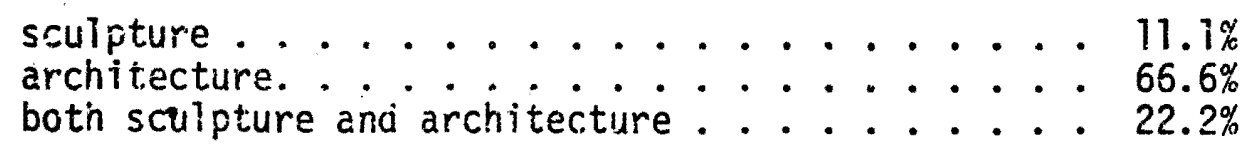

4. Have you ever been interested enough and had the opportunity to create a piece of scu?pture outside of school?

Yes: $27.7 \%$ No: $72.3 \%$

5. Have you ever been encouraged to do any sculpture?

Yes: $55.5 \%$ No: $44.4 \%$

If Yes, by whom:

Teacher ............ 8 $81.8 \%$

Other: Parent and Florist ........ 18.2\%

\section{Category II: Factors Identified as Influencing Sculpture as Artistic}

\section{Expression.}

10. Below are listed several important factors which influence the creation of a piece of sculpture. Identify which of these you consider to be the most important:
a. The sculptor's skill to make into a reality
a form which comnunicates his "idea" . . . . 22.2\%
b. The sculptor's original idea or his "intention" rather than the finished product ....... . . .
c. Both $A$ and $B$ are equally important ..... 16.6\%
d. Both $A$ and $B$ are important but $A$ is more important than $B \ldots . . . . .61 . . .1 \%$

21. Sculpture could be considered as being:*
a. A visual form of art .......... 26.6\%
b. A tactile form of art ........... . . . . . .
c. A form of art which depends upon both the visual and tactile senses ......... 73.3\%
d. A form of art which depends upon both visual and tactile senses but is more tactile than visual. . . 26.6\% 
*No response ............... 26.5\%

These responses can reflect more than $100 \%$ as some students marked answers in several categories.

24. Which of the following individuals would be more likeiy to be concerned with the visual likeness of an object? *

a. Craftsman ................ . . . . . . . . .

b. Portrait Painter ............ $82.3 \%$

c. A Portrait Scuiptor . . . . . . . . . 29.4\%

d. None of the above ............ . . . . . .

*No response .................. . . . . . . . . . . . . . .

Some students marked several selections, thus the categories reflect these responses and as a total they will compute to more than $100 \%$.

29. Select from the following those characteristics which you feel would represent the sculptural experience:*

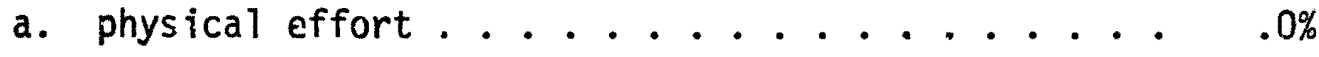
b. emotional involvement ............ . . . . . . . . .
c. technical problem solving ......... 12.5\%
d. mental effort............... $18.7 \%$
e. all of the above ............ $62.5 \%$
*No response ...................... 11. . . . . .

\section{Category III. Student Identification with Sculptural Concepts}

11. Form would refer to:

a. The outside of an object only ........ 11.1\%

b. The outer edge of an object oniy ...... $33.3 \%$

c. The irner part of an object only ........ . . . .

d. Both the interior and the exterior parts of an object ............... 55.5\% 
22. Form contains shape?

True: $88.2 \%$ False: $11.7 \%$

23. A relief sculpture is:

a. one dimensional ............ 13.3\%

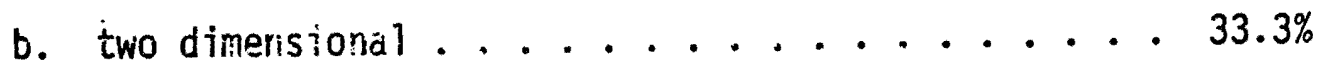

c. three dimensionai .......... $33.3 \%$

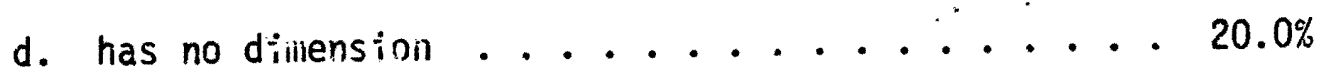

(Percentages based on those students responding.)

No response .............. 16. . . . . . . . .

26. For something to be real to a sculptor it would have to have associated with it:
a. volume
$.0 \%$
b. dimension ........................

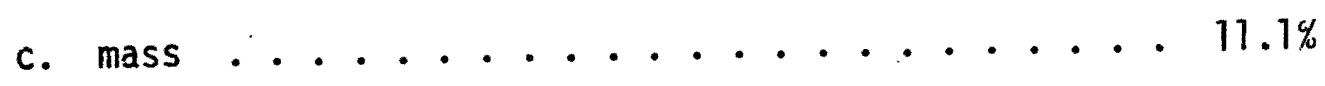
d. all of the above ............... 77.7\%
(Percentages based on those students responding.)

No response .............. . . . . . . . . . . . . . . .

38. Among the types of artists listed below, which one would be most likely to be interested in mass?

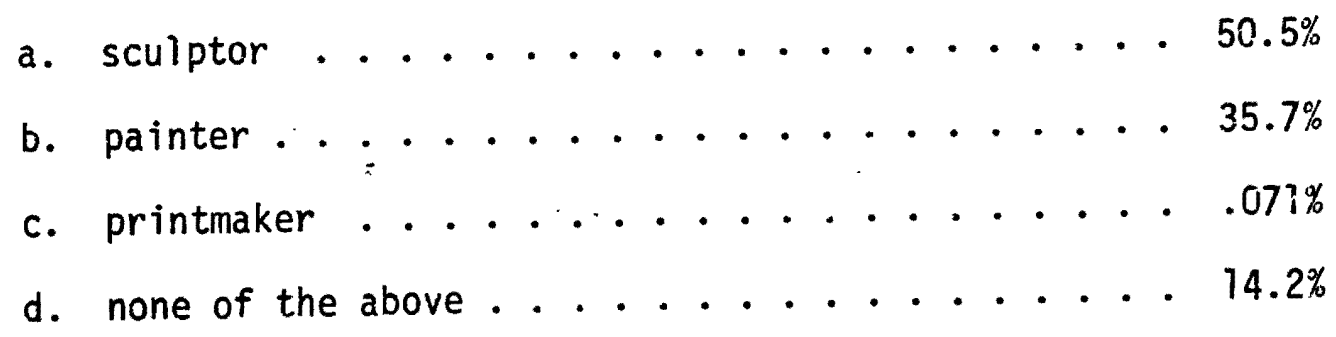

(Percentages based on those students responding.)

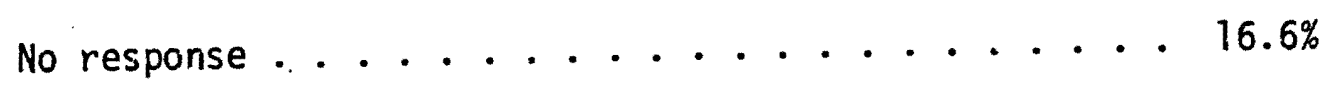

46. The amount of space which an object or form occupies or fills is referred to as its:

a. mass .............. $42.8 \%$ 
b. volume .................... 42.

c. shape ............... . . . . . . . .

d. texture ....................... . . .

(Percentages based on those students responding.)

No response ................. 16.6\%

41. Space and form are directly related to each other?

True: $35.7 \%$ False: $64.2 \%$

\section{Category IV: Identification of Prior Experiences with Materials and}

Techniques and the Sources of the Experiences.

6. Identify the past experiences you have had in working in materials and the techniques you have used to work in these. materiàls.

Materials:

No response . . . . . . . . 22.2\% wood ........................... 27\%

clay . . . . . . . . . . 22. 2\%

plaster ................... 16.1\%

other (glass and furnace cement were listed). . . 11.1\%

Techniques:

No response . . . . . . . . . . 27.7\%

carving .................... 27.7\%

modeling ................ $22.2 \%$

combination of carving and modeling . . . . 22.2\%

7. Identify where you have obtained previous experience in the use of materials and techniques used in sculpture.

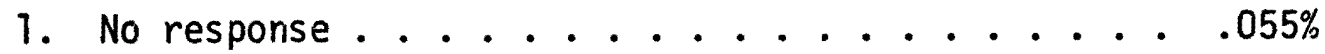

2. Junior High School .......... . . 17.6\% 
3. First Year Cirafts - Mid Kigh ........ . 70.5\%

4. Other high schools, home, etc. ....... 11.7\%

8. During the course of study this year you have had the opportunity to cast crafts products in both ceramics (piece moli) and jeweiry (cere perdue or lost wax). Do you fee! that your experiences from these units of study will be useful to you in the casting of a piece of sculpture? Please explain.

The following is a summary by this author of the ariswers obtained by categorizing them as follows:

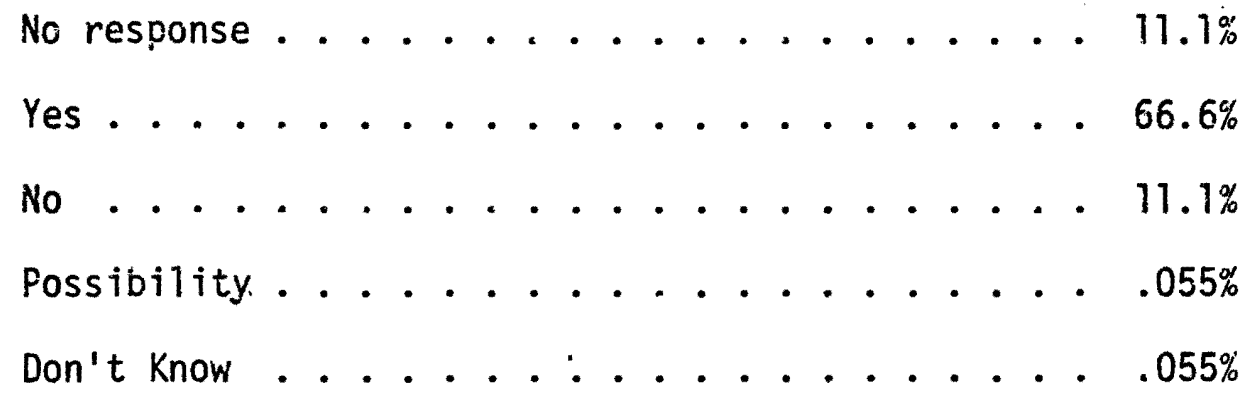

Category V: Student Ability to Understand the Concept of the Relationship Between Craftsmanship and Design.

15. Identify which of the following factors you feel would separate a sculptor from a craftsman:*

a. His skill or ability to weld ....... 27.7\%

b. His ability to cut stone ......... 16.6\%

c. Communicating an idea, message or feeling through the material with which he is working ....... 77.7\%

d. His ability to use tools ........... 11.1\%

*Some of the students selected more than one answer to this problem, thus this is reflected in the percentage figures.

32. What do you consider to be of more importance to a sculptor:
a. His creative idea or thought which he intends to communicate ............. 57. . . .
b. His ability to use tools ......... 28.5\%
c. His awareness of materials ......... . . . . . . . 
d. His ability to make use of materiais ..... $42.8 \%$

No response ................. 16.6\%

Some students selected more than one answer to this question. These figures are reflected in the percentage figure.

37. If you were asked to compare a craftsman and a sculptor, which of the following characteristics would you feel are likely to be identified with the sculptor and not the craftsman:

a. Ability to use materials .................. . . .

b. Skill at using toois ........... . 14.2\%

c. Imagination and originality ........ 50.0\%

d. All of the above are characteristics of both the craftsman and the sculptor .......................

(Percentages based on those students responding.)

No response ................... 16.6\%

39. Which of the following individuals do you feel would be considered a craftsman rather than a designer:
a. an architect ...................... 21.
b. a carpenter ............ 6 64.2\%
c. portrait painter . . . . . . . . . . . . . .
d. sculptor ................... 35.7\%
These figures reflect the fact that several students indicated two categories.

Category VI: Student Ability to Identify with Various Methods, Techniques, and Approaches to Sculpture.

16. Identify those materials listed below in which the sculptor could use the additive approach to sculpture:
a. clay
$88.2 \%$
b. concrete .............. $70.5 \%$
c. marble ................ $11.7 \%$ 
d. none of the above ............ . . . . . . $8 \% \%$

Figures based on those seventean students responding. No response . . . . . . . . . . . . . . . . . . . . . .

28. The modeing technique in sculpture is considered to be:

a. an additive approach only .......... . . . . .

b. a subtractive approach only ......... . .063\%

c. neither additive nor subtractive ...... . .063\%

d. a combination of both additive and subtractive approaches ............. $81.2 \%$

e. no responses ............ . . 11.1\%

36. If a sculptor were using a piece of marble as a material, he would use which of the following methods of sculpture:
a. direct ............... $21.4 \%$

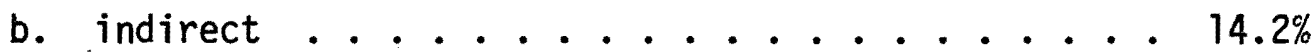
c. both direct and indirect ......... 50.0\%
d. neither direct nor indirect ........ 14.2\%
(Percentages based on those students responding.)

No response ............. 16.6\%

40. Below are listed four techniques of working in sculptural materials. Select those which a sculptor who was working in a plaster material would use:

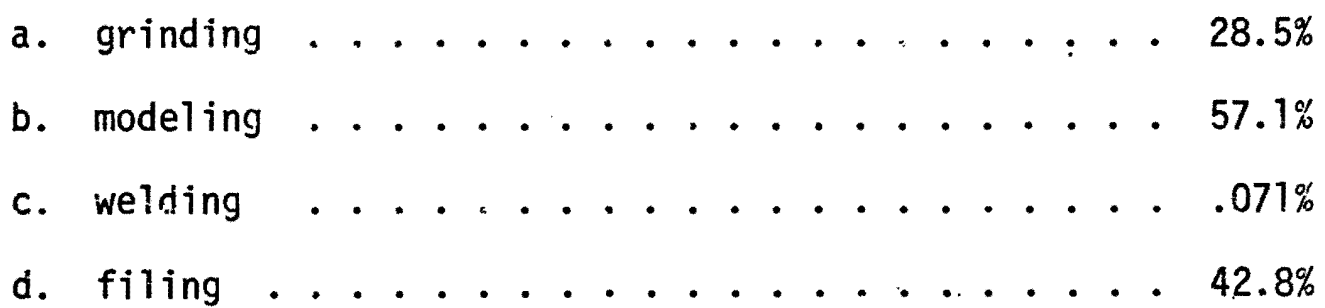

These figures reflect the selection of several processes being used in plaster materiai. 
43. If a sculptor were to carve in wood, he would be using which of the following methods of sculpture?

a. direct .................. 46. $1 \%$

b. indirect ............... . 38.4\%

c. both direct and indirect ............ . . . . . . . . .

d. reither direct nor indirect ........... . . . . . . . . . .

No response .................. 27.5\%

45. In making an aluminum casting, a sculptor would be using which of the following methods of sculpture?

a. direct ............... . . 30.7\%

b. indirect ................ 23.7\%

c. both indirect and direct .......... $38.4 \%$

d. neither direct nor indirect ............ . . . . . . . $6 \%$

(Percentages based on those students responding.)

No response . . . . . . . . . . . . . . 27.7\%

Category VII: Student Evaluation of Engineering Problems Associated with Sculpture.

13. Below are a few common materials used in sculpture. Identify those which you feel would require the use of an armature:
a. stone ................. . . . . . . . . . . $55 \%$
b. wood ......................... $11 \%$
c. clay ................. $72.2 \%$
d. aluminum ................. . . 61.1\%
e. plaster ..................... $61.1 \%$

25. An armature is a:

a. form made of clay ............... . . . . . . . .

b. series of mold pieces which are put together and

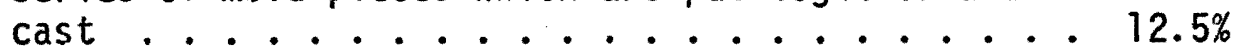


c. a framework for supporting soft materials such

as clay....................... $81.3 \%$

d. a moid filled with moiten materiar ...... . . . . . $2 \%$

Nc response ..................... $11.1 \%$

Category VIII: Ability of Students to Associate with Material Durability.

9. Below are listed five common scuiptural materials. Arrange them in order, listing what you feel is the most durable or longest lasting first and least durable last. (Match letter to the correct runiber.)
a. stone
i. matal
c. wood
d. plaster
e. unfired clay
1.
2.
3.
4.
5.

Responses:

1st. Materials:

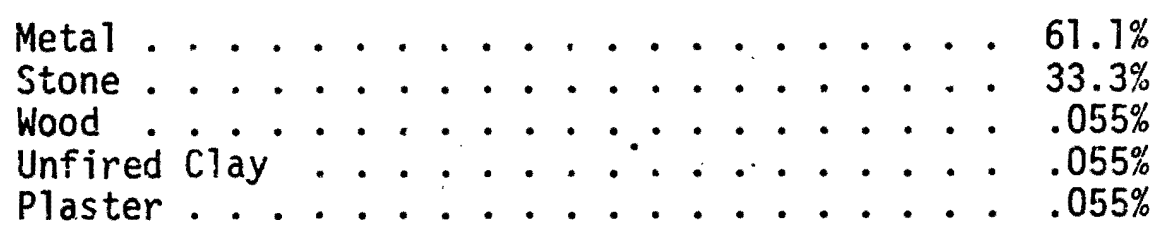

2nd. Stone ................ $61.1 \%$ Metal ................ $27.7 \%$ Wood ................. $11.1 \%$

3rd. Wood ................... $72.2 \%$

Plaster
Stone

4th. Plaster ............... . $72.2 \%$

Wood ................ 16.6\%

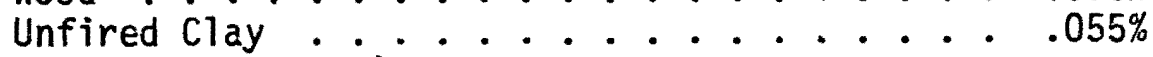

5th. Unfired Clay . . . . . . . . . . $88.8 \%$

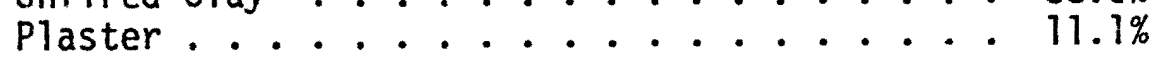

18. Identify the material or materials which you feel could not be placed in a location which had contact with the weather:

a. Stone.................. . . . . . . . .

b. Plaster ....................... $94 \%$ 
c. Hood .................. $38.8 \%$

d. Concrete .............. . . . . . . . . .

e. Aluminuni ......................... 11\%

20. Different materials possess different structural strengths and this characteristic influences the sculptor's choice of material. Below are listed five materials useful to the sculptor. Arrange them in order as to how hard the structure of the materials is: (These were arranged as follows.)
a. concrete
b. aluminum
c. plaster
d. wood
e. wax
1.
2.
3.
4.
5 .

Responses:

$1 s t$.

Material:

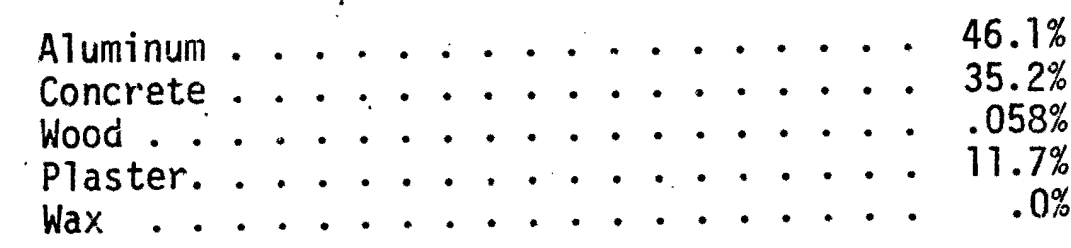

2nd.

Concrete . . . . . . . . . $52.9 \%$

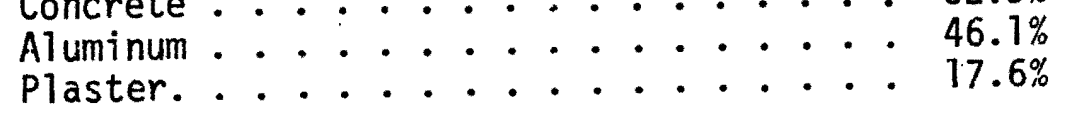

3rd. Wood ............. $76.4 \%$

4th. Plaster ............ $64.7 \%$

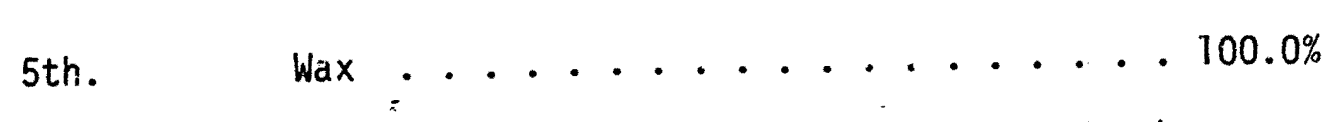

35. If the following materials were to be placed outside where they could be in contact with the weather, which would most likely hold up longer than the others:
a. Wood
$.071 \%$
b. Plaster
$.0 \%$
c. Concrete
$28.5 \%$
d. Aluminum 
Cateigory IX: Student Aiwareress of Choice of Material on Technique Used.

19. If you wished to sketch out an idea in a three dimensional form ouickly, which of the following materials would you fee? the best to use:

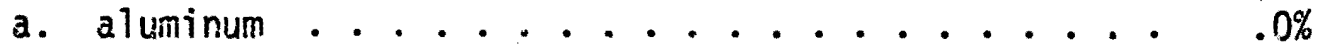
b. wood ..........................
c. clay ............... $100.0 \%$
d. plaster ..................... $0 \%$

Category X: Student's Ability to Relate to the Effect of Materials on

the Selection of His Tools.

17. If a sculptor were to sketch out a piece of sculpture in clay he would probably use one of the following tools in preference to the others. Identify the tool:
a. knife............... $77.7 \%$

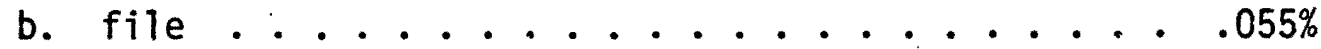
c. chisel .............. . . . . . .
d. $\operatorname{rasp} \ldots \ldots \ldots . . \ldots 16.6 \%$

27. Identify the tool or tools from those listed below which would be useful to a sculptor working in wood:
a. file..........................
b. gouge .............. 64. $64 \%$
c. hacksaw ............. 11. . . . .

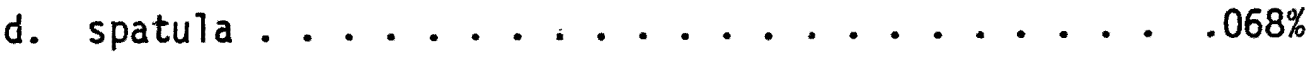
e. $\operatorname{rasp} \ldots \ldots \ldots . . . \ldots 76.4 \%$
f. chisel ..................... $94.1 \%$

31. If the sculptor were working on a casting of a piece of sculpture in metal, which of the following tools would he use:
a. grinder
$92.8 \%$
b. file
$78.5 \%$ 
c. gouge ..................... . . . . . . . . . 1\%

d. chise? ......................... . . . . 1\%

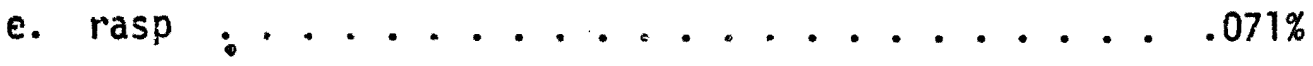

No rasponse ...................... 16.6\%

\section{Category XI: Ability of this Group of Students to Associate with the}

\section{Casting Process.}

12. A casting is:

a. The original clay model before a mold is made . . . .055\%

b. A large vat used for pouring molten metal ..... . . . 555\%

c. A form of clay made over an armature . . . . . .055\%

d. The final positive nodel after it has been removed from the moid.............. $83.3 \%$

14. Is there ary advantage in making a mold of a clay piece?

Yes: $88.2 \%$ No: $11.7 \%$

32. An alloy refers to:

a. Another element which is added to a metal to strengthen it ......................... 53\%

b. The dirt or other metal impurities which rise to the surface during the melting of aluminum . . . . . $067 \%$

c. A material placed between the various pieces of a mold to allow the pieces to separate. . . . . 13.3\%

d. None of the above . . . . . . . . . 26.6\%

33. The final sculptural form which is taken from a mold and finished is referred to as the:

a. mold .................. . . . . . . . . . .

b. casting ................. $71.0 \%$

c. armature ............................. ...

d. model .................... 14.2\% 
No response .................... 16.6\%

34. The heat range in which aluminum will become molten is:
a. $950^{\circ} \mathrm{F}$ to $1250^{\circ} \mathrm{F}$
b. $1300^{\circ} \mathrm{F}$ to $1700^{\circ} \mathrm{F} \ldots \ldots 14.2 \%$
c. $1800^{\circ} \mathrm{F}$ to $1900^{\circ} \mathrm{F} \ldots \ldots . \ldots 50.0 \%$
d. $1500^{\circ} \mathrm{F}$ to $1700^{\circ} \mathrm{F} \ldots \ldots . \ldots 21.4 \%$

42. Identify which of the following materials would be placed between the pieces of a mold to allow them to separate:
a. plaster.................. 14.2\%

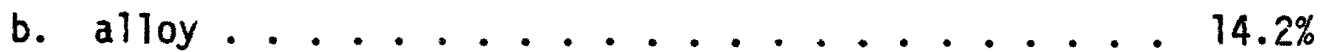

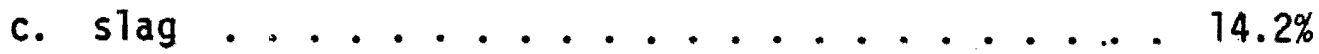
d. clay stip ............... . . 57.1\%

44. The large vat used for melting is referred to as the:
a. furnace .............. $64.2 \%$

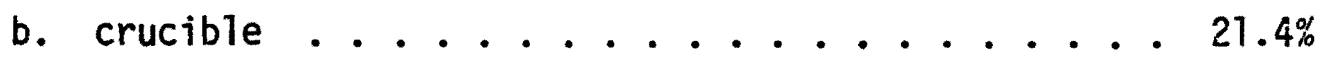
c. cast ..........................

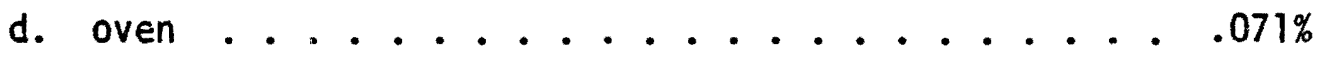

\section{CATEGORY XII: Identified Student Preference for Use of Sculptural}

\section{Materials.}

48. Below are a number of materials used in sculpture. Arrange them in the order in which you would prefer working if given a choice.

$\begin{array}{ll}\text { 1. concrete } & \text { a. } \\ \text { 2. aluminum } & \text { b. } \\ \text { 3. plaster } & \text { c. } \\ \text { 4. wood } & \text { d. } \\ \text { 5. wax } & \text { e. }\end{array}$

Responses:

1st. Materials: 


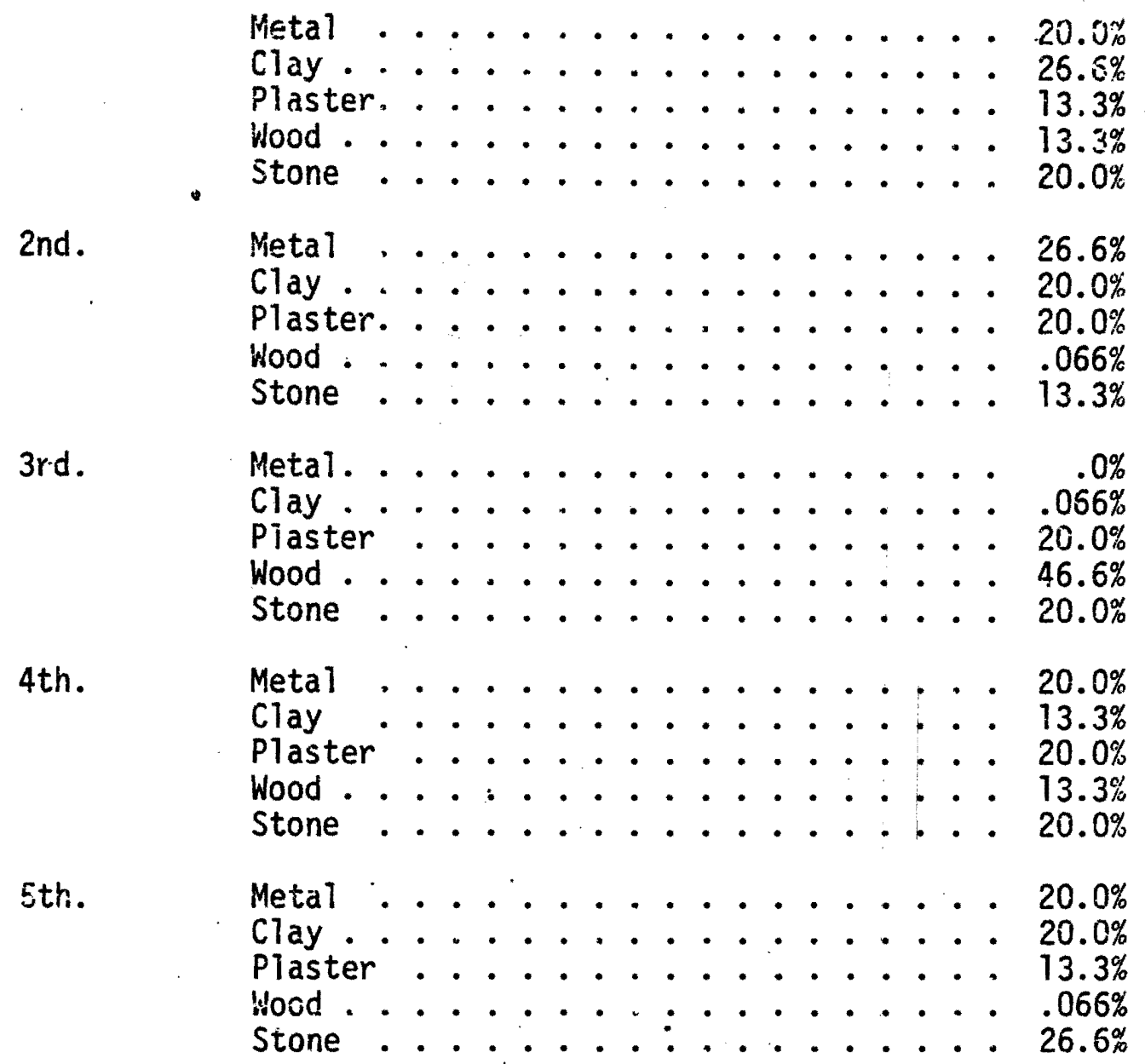

Category XIII: Student Identification of Materials Preferred for Casting.

47. If you were given a choice between plaster, concrete, or aluminum for making a sculptural casting, which would you select?

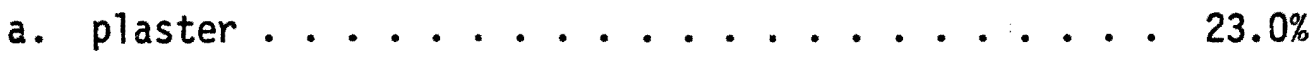
b. concrete ............................

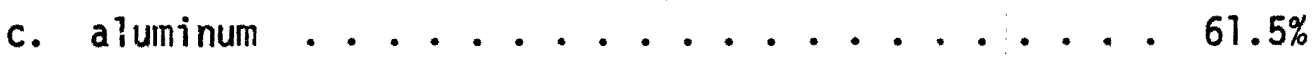

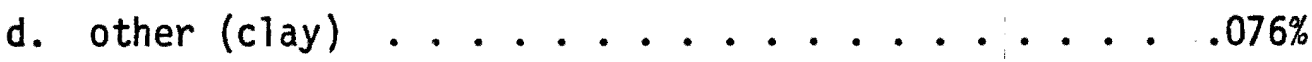

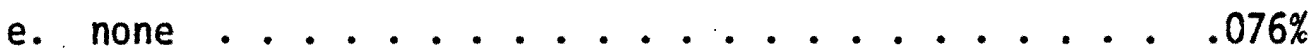

